\title{
Promoting Eco-innovations to Leverage Sustainable Development of Eco-industry and Green Growth
}

By

\author{
${ }^{1}$ Dr. A.N.Sarkar
}

\begin{abstract}
In the modern world, ecology and the economy are on cross roads. With the increasing pace of globalization and economic liberalization, giving birth to the rapid growth of consumerism by the modern civilization, there is growing consciousness to move gradually towards green growth with sustainability. This is now becoming possible by enhancing eco-consciousness both among the producers as well as the consumers. The chosen path is obviously to go in for more and more eco-innovations to provide complementarily to industrial production without sacrificing much on the production as well as economic front. Renewable alternate technologies - widely known as ecotechnologies, are now being developed with massive investment on R\&D activities by several research organizations across the world to achieve this mission. To leverage the gains from eco-innovations and achieved through proactive and carefully planned organizational and R\&D support, there seems to be a surge in the growth of Ecoindustries; which in turn, are getting increasingly organized as a chain of eco-industry, by constantly evolving replicable as well as sustainable eco-industrial models in the emerging sectors of economy, prominently in the EU countries.

The paper takes a holistic and strategic review on how the Eco-innovations and their ecospecific promotional and developmental efforts are stimulating the sustainable development of Eco-industries and enhancing Green growth by setting up of demonstrable Eco-industrial models in multi-sectoral areas in Europe and the other parts of the world. The paper also provides a brief account of various corporate and entrepreneur initiatives taken in developing sustainable Eco-industrial business models and the methodologies to measure the impact of eco-innovation projects.
\end{abstract}

Key Words: Eco-innovation, Eco-industry Models, Green Growth, Green Marketing, Eco-efficiency, Eco-innovation Impact measurements

\section{Eco-Innovation: Genesis and Definitions}

Innovation refers to 'the implementation of a new or significantly improved product (good or service), or process, a new marketing method, or a new organizational method in business practices, workplace organization or 
external relations' (Eurostat, 1999, 2010). The most common usage of the term "eco-innovation" is to refer to innovative products and processes that reduce environmental impacts. This is often used in conjunction with 'eco-efficiency' and 'eco-design'. Eco-innovation refers to all forms of innovation - technological and non-technological, new products and services and new business practices - that creates to creation and development of new business opportunities and benefits the environment by preventing or reducing their impact, or by optimizing the use of natural resources. Eco-innovation is closely related to the development and use of environmental technologies and also to the concepts of eco-efficiency and ecoindustries. The common aim is to contribute to more sustainable production and consumption patterns. Practical examples of eco-innovation include processes to recover valuable substances from waste water, more efficient food packaging, and the production of construction materials from recycled waste, eco-products and new management methods.

Eco-innovation is altogether a new concept. In the MEI (Measuring EcoInnovation) project for the European Commission, eco-innovation is defined as "the production, assimilation or exploitation of a product, production process, service or management or business method that is novel to the organization (developing or adopting it) and which results, throughout its life cycle, in a reduction of environmental risk, pollution and other negative impacts of resources use (including energy use) compared to relevant alternatives". Partly building on this definition, eco-innovation is defined in the OECD (2009) Report on sustainable manufacturing and eco-innovation as "the creation or implementation of new, or significantly improved, products (goods and services), processes, marketing methods, organizational structures and institutional arrangements which - with or without intent - lead to environmental improvements compared to relevant alternatives" (OECD, 2008a). Both definitions are in line with the Oslo Manual definition of innovation, which includes the implementation of a new technology that was developed by a different firm or institution. For example, following the Oslo Manual, a firm can innovate (or eco-innovate) by purchasing cleaner production technology from a supplier and implementing the technology into its production line. The Oslo Manual is important here because it is the guidebook for the official innovation surveys of almost all OECD countries.

The eco-innovations may, as other innovations, be technical, organizational or marketing innovations as long as they improve the "green competitiveness" of a company (Kemp and Andersen 2004, Andersen, 2004, 2008). Hence the ecoinnovation concept is more inclusive than earlier definitions of environmental technologies which typically have had a mainly technical orientation. But it is also more inclusive in another sense. While the clean tech concept also has a market orientation and is a concept very close to the eco-innovation concept, the eco- 
innovation concept has the advantage that it encompasses the entire innovation process from idea generation to value creation on the market. This also means that the concept can be linked to the wider "sustainable consumption and production" concept (SCP), though the two concept areas have been little linked so far (Andersen, 2008, Tucker, 2004).

A number of definitions of eco-innovation was made, and among these, according to the definition made European Commission, eco-innovation is every kind of innovations which can be sustained by reducing its effects on the environment and obtaining the use of natural resources, including energy, more effectively and efficiently, and which aims important and demonstrable advancement toward development (Carrillo-Hermosilla et al, 2010). When we evaluate according to the definition of eco-innovation presented above, eco -innovations can be divided into two categories; environmental innovations and non-environmental innovations. In terms of sustainable development, environmental innovations gained importance. According to any classification, we can classify the ecoinnovations as technological eco-innovations, organizational eco-innovations, ecoinnovations associated with business parks, and social innovations. A more environmentalist life-style and innovations associated with the habits of consumptions, and accepting the new arrangements such as Renewable Energy Act can be given as examples for social eco-innovations (Esders, 2008).

Another classification about this issue is that made by Andersen (2008). According to this classification, eco-innovations are divided into 5 categories. There are extension eco -innovations, integrated eco - innovations, alternative product eco-innovations, macro-organizational eco-innovations, and general purpose eco- innovations. Extension eco-innovations are the products (or services) improving the general environmental performance of customer. These innovation are environmental solutions in part of pool (a number of technologies and services cleaning emissions, diluting, recycling, measuring, controlling, and carrying the emissions) and source (deriving the natural resources and energy). Integrated eco-innovations (clean technological processes and clean products) make the production process or product compared to the similar processes. They contribute to be solved the environmental problems within companies or the other organizations (public organizations, families). Macro-organizational ecoinnovations (new organizational structures) express the new solutions for ecoeffective ways of affecting the society. This refers to the new ways considering our product and consumption in more systematic level.

\section{Benefits of Eco-innovation}


Eco-innovations help to reduce environmental burden or to reduce the costs of doing so. There is no guaranteed that the use of eco-innovations will improve the quality of the air and the quality of other receiving media (water, soil). Environmental quality is often viewed in relation to growth. When the quality of the environment improves we speak of an absolute decoupling, when the quality of the air or water deteriorates despite the use of environmental technologies we speak of a relative decoupling. For the eco-innovator there are both direct and indirect benefits.

The direct benefits for the innovator consist of: operational advantages such as cost savings from greater resource productivity and better logistics; Sales from commercialisation. The indirect benefits for the innovating company consist of: better image, better relations with suppliers, customers and authorities, an enhanced innovation capability overall - thanks to contacts with knowledge holders, Health and safety benefits, greater worker satisfaction. These benefits must be weighed against costs for the company. Surveys show that the majority of companies know very little of either the costs or benefits of their environmental activities. Of course, eco-innovations should be valued from a societal point of view, not just a business point of view. From a social welfare point of view, ecoinnovations are desirable if it contributes to overall welfare in the sense of wellbeing (not economic growth). An Eco-innovation is "any form of innovation resulting in or aiming at significant and demonstrable progress towards the goal of sustainable development" through reducing environmental impacts, enhancing resilience to environmental pressures or achieving a more efficient and responsible use of natural resource. The European Commission estimates the annual turnover of "European eco-industries" at 319 billion euro. This corresponds to $2.5 \%$ of EU gross domestic product (GDP). In the past two years, $45 \%$ of the European companies operating in manufacturing, agriculture, water and food services have eco-innovated. Apart from in the energy and climate protection sectors, eco-innovation has been promoted "relatively slowly". According to the Commission, eco-innovation needs to be accelerated in order to boost resource productivity, efficiency and environmental protection. Ecoinnovations can benefit both the producers and the consumers in different manner.

\subsection{Benefits of Eco-innovations for Producers}

As it was said above, the eco-innovations have a lot of direct positive effects on environment. In advance it was not possible to estimate the relation between economic level of the country and preferred effects of eco-innovations; nevertheless we assumed that at least one effect of eco-innovations will be related 
to economic level of the country. Correlation between benefits of eco-innovations for producers and economic level of Country is shown in Table 1.

Table 1: Correlation between benefits of eco-innovations for producers and economic level of Country

\begin{tabular}{l|r|r|r|r|r|r}
\hline & $\begin{array}{c}\text { Reduced } \\
\text { material }\end{array}$ & $\begin{array}{c}\text { Reduced } \\
\text { energy }\end{array}$ & $\begin{array}{c}\text { Reduced CO2 } \\
\text { footprint }\end{array}$ & $\begin{array}{c}\text { Replaced } \\
\text { materials }\end{array}$ & $\begin{array}{c}\text { Reduced } \\
\text { pollution }\end{array}$ & Rec \\
\hline GDP & -0.05 & 0.09 & 0.52 & 0.22 & 0.03 & \\
\hline Expenditures on R\&D & 0.10 & 0.12 & 0.36 & 0.23 & -0.02 & \\
\hline Turnover & 0.32 & 0.29 & 0.18 & 0.02 & -0.07 & \\
\hline
\end{tabular}

Source: Eurostat Annual Report - 2010

\subsection{Benefits of Eco-innovations for Users}

In the context of existence of alternative products or services (eco-friendly vs. eco-unfriendly products) on market and demand of customers it was possible to assume some relation between the effects of eco-innovations for users and economic level of country. On the other side we didn't want to overestimate this assumption because the economic level of customer's country is more important than the economic level of producer's country and the relation between effects and economic level of customer's country it is not possible to examine. This part of analysis was supplemented by Eurostat (2010) with indicator of existing procedures to regularly identify and reduce environmental impacts where it was possible to expect that in more developed countries these procedures will be more frequent than in less developed countries (but presence of such procedures is low in whole Europe). Correlation between benefits of eco-innovations for users and existence of procedures and economic level of country is shown in Table 2.

Table 2: Correlation between benefits of eco-innovations for users and existence of procedures and economic level of country

\begin{tabular}{l|c|c|c|r|}
\hline & $\begin{array}{c}\text { Reduced } \\
\text { energy }\end{array}$ & $\begin{array}{c}\text { Reduced } \\
\text { pollution }\end{array}$ & $\begin{array}{c}\text { Recycling of } \\
\text { product }\end{array}$ & $\begin{array}{c}\text { Existence of } \\
\text { procedures }\end{array}$ \\
\hline GDP & 0,30 & $-0,03$ & 0,33 & 0,02 \\
\hline Expenditures on R\&D & 0,15 & $-0,08$ & $-0,02$ & 0,13 \\
Turnover & 0,23 & $-0,10$ & 0,16 & 0,11 \\
\hline
\end{tabular}

Source: Eurostat Annual Report - 2010

The results of correlation shown in Table 2 are not too interesting; all the analyzed relations are only slightly or not at all significant. On the other side the confirmation of independence of these effects and procedures on the economic level of countries can be positive finding of carried out analysis. 


\section{Evolving Green Business Innovation Model}

Nature is bountiful. Over the centuries, the endowments of nature have been exploited by anthropogenic actions for providing livelihood support for human beings and other living entities of the planet. With the huge growth of human population, rapid pace of industrialization and urbanization for industrial production the ecological balance has been disturbed; and the resource constraints have been alarming. This trend is detrimental for futuristic growth without further damage to environment. Hence, some way down the line, there is a growing realization now that we must give back to nature what we extract from nature without affecting production and productivity as well as economic growth. In other words, growth rhythm must be maintained in a sustainable manner for betterment of the lifestyle and the society at large. Relying heavily on this core principle, in recent time, several business models have been tested and evolved based on eco-innovations.

It is a well-established fact that innovation is essential for a sustainable long-term growth path for any country. It has also become widely accepted that resource scarcity, environmental and climate issues need to be addressed at government, consumer and business level if we are to retain our standards of living and create long-term growth. Businesses are also increasingly recognizing that the greening of their own business or value chain by improving resource productivity may increase both their short-term and long-term competitiveness and create new markets. Some companies innovate their business models and improve their resource productivity by substituting to greener inputs, selling greener products and services, while others implement cradle-to-cradle elements in their business model or apply functional sales systems that may change consumption patterns and practices throughout their entire value chain. In a broad sense this could all be characterized as greening of the companies' business models.

In the eco-innovation literature, there has so far not been established an internationally acknowledged definition of green business model innovation, nor has there previously been any structured way of describing these concepts as a whole. There are many terms in the public and academic debate about how companies green their business and how they are categorized as green companies. These terms are ranging from the more product-oriented perspectives like clean-tech companies that produce e.g. renewable energy such as wind and solar power, resource efficient products such as energy efficient pumps, to service-oriented 
companies which provide environmental services, to companies that implement more process-oriented initiatives in their businesses or whole value chain such as environmental ISO-standards, cradle-to-cradle, corporate social responsibility (CSR) or green reporting etc. Hence, Green Business Model Innovation can be defined as: Green business model innovation is when a business changes part(s) of its business model and thereby both captures economic value and reduces the ecological footprint in a life-cycle perspective - the greener the business model innovation is and the higher potential for creating radical ecoinnovation.

Green business model innovation might not always be due to a one-time change with the aim of green and economic effects but be a result of continuous (efficiency) changes of the business model over time which eventually ends up being categorized as green business model innovation. Eco-innovation can include both environmentally motivated innovations and unintended environmental innovations, as the environmental benefits of an innovation may be a side effect of other goals such as reducing costs for production or waste management (Machiba, 2008, 2010). Eco-innovation reflects the concept's explicit emphasis on a reduction of environmental impact, whether such an effect is intended or not (Machiba, 2010). It can be technological or non-technological (organizational), its impact can vary, and according to Machiba (2010) its scope depends on the targets ; such as institutions, organizations, marketing methods, processes \& products as well as mechanisms; such as pollution control, clean production, eco-efficiency, industrial ecology, modification and redesigning, creations etc. as may be seen in Figure 1. 


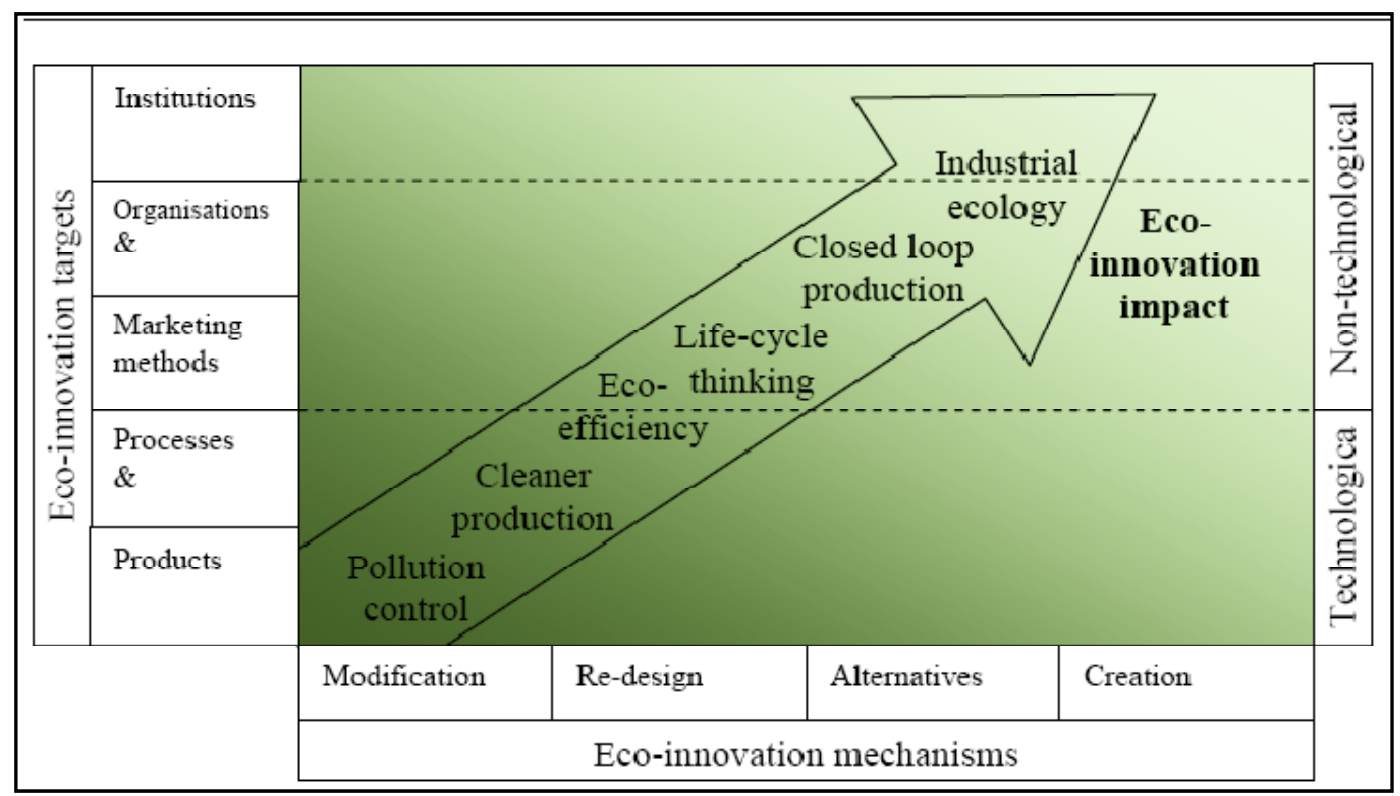

Figure 1: Conceptual relationships between sustainable manufacturing and eco-innovation (Machiba, 2010)

\subsection{The Concept of Eco-design}

To manage the negative environmental impact of products, a significant effort is put in remedial actions such as waste management, pollution control and cleaning up production and disposal sites. Whilst necessary, such actions alone do not have the potential to reduce the environmental impact of our products to a degree that facilitates a sustainable society (Schmidt-Bleek 1999). Interventions of the targeted eco-products at the design stage of products have a much higher potential to improve their environmental performance (Schmidt-Bleek 2004, 2009, 2010). These activities are usually termed as eco-design (Brezet et al, 1997). Interventions to reduce environmental impacts require innovation, which can happen at various levels. Crul et al (2009) classify three different types of innovation: incremental, radical and fundamental. This is to be understood as a scale of innovation, with incremental at one end and fundamental at the other end, rather than three distinct categories. Incremental innovations are most commonly associated with step by step improvements of existing products through redesign processes. By contrast, new product design or even the development of completely new concepts requires radical or fundamental innovation. In the context of the aim of sustainable development, Crul et al. (2009) pointed out that while incremental innovation is important, only radical and fundamental can sufficiently reduce the environmental impact. To bring in grater clarity about Eco-Design OECD's 
Green Framework (OECD, 2011a\&b ) can be used as a good starting point; as shown below in Figure 2.

\subsection{Evolving Green Growth Strategy}

\subsubsection{Concept and Elements of Green Growth}

Green growth, as agreed at the fifth Ministerial Conference on Environment and Development in Asia and the Pacific, is a strategy for achieving sustainable development. It is focused on overhauling the economy in a way that synergizes economic growth and environmental protection, building a green economy in which investments in resource savings as well as sustainable management of natural capital are drivers of growth. An economy which is in closer alignment with sustainable development objectives provides opportunities for using financial

Figure 2: OECD'S Green Growth Framework to develop Good Eco-Designs 


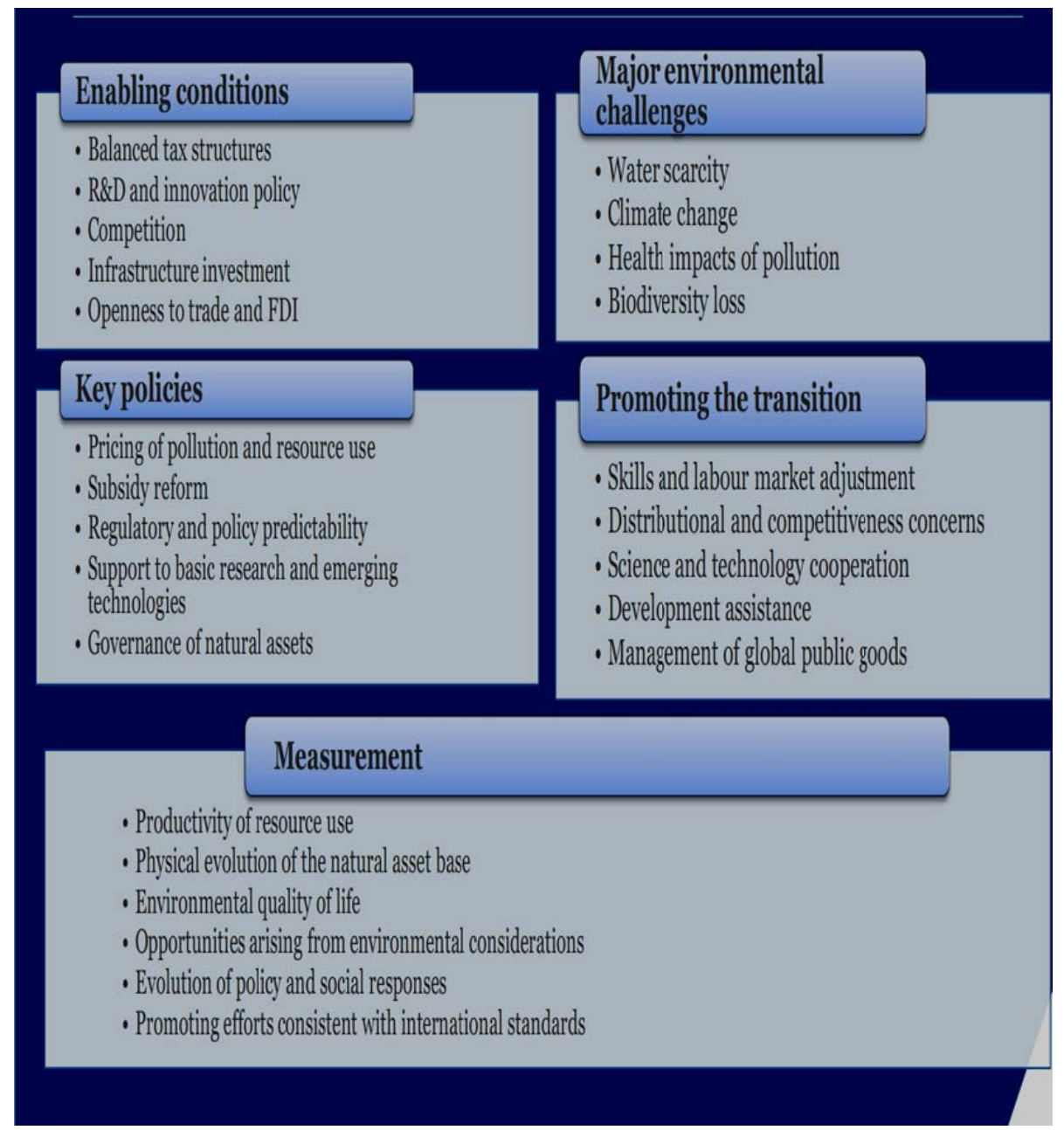

Source: OECD (2011a\& b) Towards Green Growth

resources better to meet development needs and reducing the vulnerability of socioeconomic systems to environmental change and resource constraints. Green growth strategies can help economies and societies become more resilient as they work to meet demands for food production, transport, housing, energy and water. Strategies can help mitigate the impacts of adverse shocks by reducing the intensity of resource consumption and environmental impacts, while alleviating pressure on commodity prices. Green growth also offers competitive advantages to those countries that commit to policy innovations. The global market for green goods and services is vast and growing fast, offering countries the dual benefit of prosperity and job creation. In the Green Growth Report published in 2008, the following key aspects were identified as key requirements for sustained economic growth: high savings and investment rates, particularly in infrastructure and 
education, functioning competition and acceptance of structural change, effective government, a functional capital market, and a good environment for business and investment. In Green growth perspectives eco-friendly action is encouraged by setting positive incentives; environmentally damaging action loses its appeal through sanctioning mechanisms. The scope of eco-innovation may go beyond the conventional organizational boundaries of the innovating organization and involve broader social arrangements that trigger changes in existing socio-cultural norms and institutional structures. OECD's Green growth strategy can be best illustrated in terms of the following cardinal elements covered under the approved action plan (Fig 3).

Figure 3: OECD's Green Growth Strategy Framework

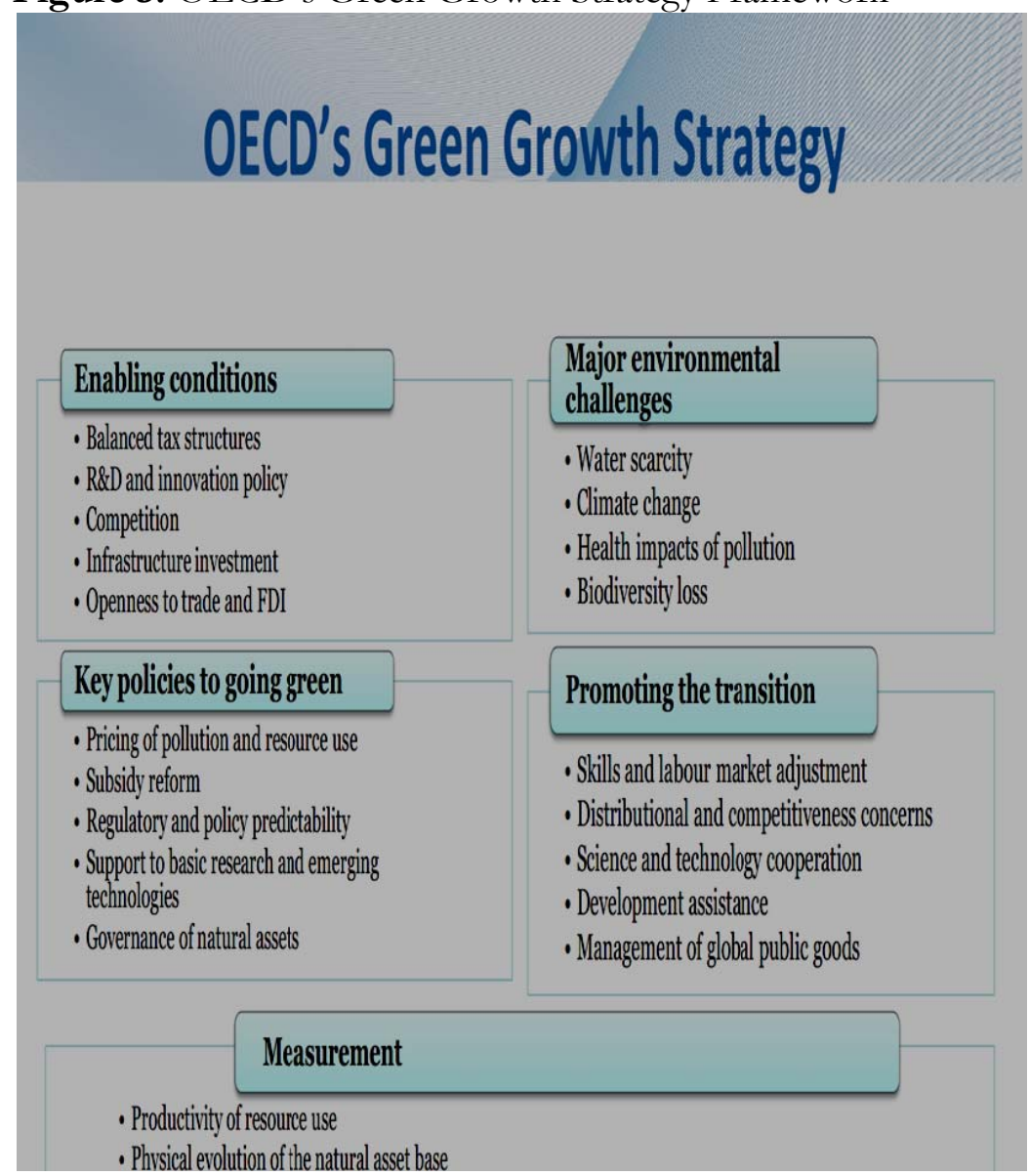

Source: OECD (2011 a\&b) -Towards Green Growth

Possible measures for strengthening demand for eco innovations include introducing standards, increasing public sector demand and promoting technology transfers. Measures to promote technology transfer, as well as the development of 
local expertise to utilize, adapt and improve these technologies, are regarded as highly significant.

\subsection{Definitions of Green Business Models}

Compared to eco-innovation, business model is a rather old concept, which emerged to academic literature together with criticism, or to complement the concept of business strategy of Porter \& van der Linde (1995). In recent years, the business model has been the focus of substantial attention by both academics and practitioners. The modern view on business model concept became prevalent with the advent of the personal computer and Internet in the mid 1990s (Magretta 2002; Zott et al. 2011), and it has been gathering momentum since then. According to review made by Zott et al. (2011), since 1995 there have been 1,177 papers published in peer-reviewed academic journals in which the notion of a business model is addressed. Generally speaking, business models are about converting company's potentials and capacities into economic value (Chesbrough and Rosenboom 2002, Chesbrough, 2003). At the centre of any business model is the company's value proposition - the products and services that yield tangible results for the company's target customers. A company's value proposition is what makes it different from its competitors (Osterwalder, 2004, Osterwalder et al, 2005; Osterwalder and Pigneur, 2010), and can create the competitive advantage. Therefore companies should always be in search for more innovative business models. To support that, it has been found by Johnson et al. (2008), that business model related innovation is becoming more important for success of company than product or service innovation.

According to Johnson et al. (2008), a business model consists of four interlocking elements that, taken together, create and deliver value. These elements are customer value proposition (CVP), profit formula, key resources and key processes. Other scholars have attempted to provide different parts of business model ontologies. Business model ontology by Osterwalder (2004) is a conceptualization and formalization of the essential components of a business model into elements, relationships, vocabulary, and semantics. According to Osterwalder et al. (2005) a business model is a conceptual tool that contains a set of elements and their relationships and allows expressing the business logic of a specific firm. It is a description of the value a company offers to one or several segments of customers and of the architecture of the firm and its network of partners for creating, marketing, and delivering this value relationship capital, to create profitable and sustainable revenue streams.

Fundamentally "eco-technologies", now superseded by the concept of "ecoinnovations", are technologies or services which remedy environmental problems. Understanding eco-innovation then entails understanding the changing 
relationship between society and nature and the attempts to develop novel solutions to deal with man-made environmental degradation. Environmental technologies are a central element of the European Union's approach to major environmental challenges such as climate change, natural resource scarcity and dwindling biodiversity. Viable technological solutions are already available to remedy many of the environmental challenges we face, but their commercial takeup can be hampered by numerous obstacles. If environmental technologies are to be adopted widely, economic and regulatory barriers must be removed and research, investments and awareness must be promoted. Opportunities for environmental technologies are greater in the European single market than in smaller national markets. Research is crucial to realizing the full potential of the fast-growing eco-industries sector and to triggering a wave of innovation and job creation.

\section{Role of Eco-innovation in Transformation of Green Economies}

Most OECD governments are already regarding eco-innovation as a way to meet sustainable development targets while keeping industry and the economy competitive. For instance, in the European Union (EU), eco-innovation is considered to support the wider objectives of increasing resource efficiency, competitiveness and fostering economic growth overall. Green technologies are also considered to have promise for improving environmental conditions without impeding economic growth in the United States. In Japan, the government's Industrial Science Technology Policy Committee sees eco-innovation as a new field of techno-social innovations. In Korea, eco-innovation is at the heart of the national Green Growth Strategy. An OECD Innovation Strategy was adopted in 2010. Among others, the Strategy report highlights experience and good practices from countries around the world and points to a number of issues that deserve consideration by OECD governments, such as the need to: empower people to innovate by providing high-quality and relevant education, as well as enabling the development of wide-ranging skills that complement formal education; support small and medium-sized enterprises, which translate knowledge and ideas into jobs and wealth, frequently revealing unexploited opportunities; enact policies in support to innovative entrepreneurial efforts; finance fundamental research and development; and enable more actors to engage in knowledge sharing. Ecoinnovation needs have been reflected in the OECD Innovation Strategy, and then further enhanced in the OECD's Green Growth Strategy (OECD, 2011a). On the ground, eco-innovation has already resulted in new business models, for example by establishing eco-industrial parks that harness economic and environmental synergies between traditionally unrelated industrial producers. But in order to 
ensure long-term sustainability of such eco-industrial projects, including ecoindustrial parks there is a need to develop Sustainable Green marketing strategy.

\subsection{Sustainable Green Marketing Strategy}

For environmental advertising to be successful, a firm must first have an environmental strategy put in place (Easterling et al, 1996). Advertising strategies have changed dramatically overtime from "image" orientation to "product" orientation in the 1990s (Easterling et al, 1996). "Process" and "factual" orientations are the least utilized orientations which the some management workers suggest to be an opportunity (Easterling et al, 1996). Two dimensions of the positioning strategies of newly created Green brands are found to have as significant impact on brand attitudes: 'functional' and 'emotional' dimensions (Hartmann et al, 2005). Results of their study indicate that there is an overall positive influence of green brand positioning on brand attitude (Hartmann, et al, 2005). While the emotional dimension proves to be more effective for the product (a car) used in the study, it cannot be concluded decisively which dimensional is more effective (Hartmann et al, 2005). Both language and images can be used to craft such messages by promoting particular interests and ideologies. RiveraCamino suggests that a firm's "greening process" is not linear, but an "uneven process" which several green marketing strategists have used to target different stakeholders (Rivera-Camino, 2007).

Clearly then, green marketing should be an integral part of the overall corporate strategy for the firms specializing in green eco-products (Menon and Menon, 1997). Along with manipulating the traditional marketing mix, it requires an understanding of public policy processes. Green marketing also ties closely with issues of industrial ecology and environmental sustainability such as extended producers' liability, life-cycle analysis, material use and resource flows, and ecoefficiency. Thus, the subject of green marketing is vast, having important implications for business strategy and public policy. Firms can 'green' themselves in three ways: value-addition processes (firm level), management systems (firm level) and/or products (product level). Greening the value-addition processes could entail redesigning them, eliminating some of them, modifying technology and/or inducting new technology - all with the objective of reducing the environmental impact aggregated for all stages. Ottman et al (2006) suggested that all marketing activities must convince the consumers through identifying the basic product features by resorting to the following Strategies: (a.) Consumer Value Positioning: A firm should focus in designing a product, which is differentiated from and performs better than the alternatives. (b). Calibration of Consumer knowledge: In designing marketing communication, a firm should always present product unique features, environmental benefits and solutions that matched with 
the Customer norms and values (c). Credibility of Product Claim: By Certification of claimed green products

A firm should build confidence in the consumers' minds by presenting or communicating benefits of the product that are specific and meaningful and qualified for the consumers. While consumer's decisions are influenced by the media, as a stakeholder, the role of media cannot be ignored; and it is the only source through which a consumer receive much of environment related information (Ottman, 1993). Davis (1993) and Glaser (2009) explained that consumer want to know more about the particular and specific information about the product or service which they about to buy in case they are claimed to be environmentally friendly. Vaccaro (2009) has presented two main strategies for the companies in responding to their external environment as "proactive strategies" (First Mover) and "reactive strategies". The "proactive strategies" and "reactive strategies" move in a continuum and the response time may widely vary depending on the customer behaviour and the life-style. Companies make their offerings competitive through price/quality or prestige/image strategies from their competitors but eco-friendliness and social responsibility can make companies more profitable on a sustainable basis. In 1999, Swedish state-owned railway company SJ bought "Bra Miljöval" labeled electricity (Kaberger, 2003). Other studies by Karna et al. (2003) suggested that companies can create competitive advantage if they use innovations related to environmental sustainability rather than simply comply with the government regulations.

\subsection{Green Branding to Leverage Eco-Market Opportunities}

The "going green" movement is continuing to build momentum, and companies are quickly realizing that they better become eco-friendly now or risk losing business. Plenty of new companies are starting out as a "green" brand; older companies want to re-brand their products to be more eco-friendly. Since both new and existing customers surf the web, one can accomplish "green" branding through a variety of ways. Those companies that do not "go green", risk being branded socially irresponsible, making them vulnerable to criticism and brands at risk. Such a strong association between corporate action - and potentially inaction - on the environment and social irresponsibility leaves brands at risk unless proactive steps are taken to become green. Implications of Green Branding are widely known and the emerging green consumer purchase behavior suggests the following scenario (Environmentally-Friendly Promotional Products Can Aid Your Organization With "Green" Branding: http://www.igreenhome.com/environmentally-friendly-promotional-products-can-aid-your-

organization-with-green-branding/; Retrieved on February 4, 2011 by The iGreen-Home Team ):

- Demand for green (or greener) products will increase over time as attitudes and social norms evolve; 
- New product choices become available and information that enables consumers to make informed purchase decisions (e.g. green labels) is introduced;

- Consumers will start to shift spending to greener brands within a category;

- Consumers will increasingly prefer to purchase from companies with a brand that is perceived as green, regardless of whether or not the product that they ultimately purchase is one of the company's "green" products.

In the US alone, consumer spending on products and services, perceived to be environmentally-friendly, will double to US $\$ 500$ billion, according to the 2007Green Brands Survey conducted by Landor Associates, Penn, Schoen \& Berland Associates, and Cohn \& Wolfe (ImagePower ${ }^{\circledR}$ Green Brands Survey, 2007). Consumers not only want to buy green, they are prepared to pay a premium price for it. Nearly, 70 percent of some 2,000 people surveyed in the U.S., U.K., Germany, the Netherlands, Australia and Japan, said they would pay a premium price for green energy alternatives, such as wind, bio-energy and solar power. According to last year's poll by IBM Global Energy \& Utilities Industry, Australians were the most willing to pay more for renewable energy, but Americans said they would pay the highest premium - 20 percent or more. Consumer brands have been quick to respond to shoppers' desire to buy green. Wal-Mart announced last year that it would provide carbon ratings for all its electronics items. Procter \& Gamble, the consumer goods giant behind such brands as Gillette and Olay, has committed to selling $\$ 30$ billion worth of greener products over the next five years. Rival Unilever - makers of Dove and Lipton has pledged to reduce waste and water consumption in its supply chain. In Brazil, Unilever and Wal-Mart have built "sustainable houses" within stores which are made from recycled products, showing how to make everyday living more ecofriendly.

Marketing of Eco-products is not quite as simple as it seems. It is generally observed that the ecologically sustainable products will not be commercially viable to penetrate the market if green brand attributes are not effectively communicated. Meffert and Kirchgeorg (1993) suggest that green positioning is an essential factor in the success of green branding strategies. Green brand positioning strategies may be classified as "functional" or "emotional". A green positioning strategy based on functional brand attributes aims to build brand associations by delivering information on environmentally sound product attributes. This positioning strategy should be based on relevant environmental advantages of the product compared to competing conventional products, and may refer to production processes, product use and/or product elimination. A car 
brand, for example, may be considered environmentally sound if the models in question cause significantly lower emissions than competitors. Several Toyota car brands recently launched in the US are branded as "Green cars" because of "Zero Emission" claims.

\subsection{Eco-Innovations for Green Branding with Sustainability Focus}

'Environmental sustainability' is not simply a matter of compliance or risk management. Business is increasingly recognizing the many competitive advantages and business opportunities to be gained from eco-sustainability and green marketing. Companies of all sizes are facing the material impact of regulatory requirements, media scrutiny, stakeholder concerns and customer expectations. Green businesses have a two-pronged equation to solve when considering how to profitably bring sustainability into the fold. One entails their internal culture, processes, materials and related supply-side issues. The other is how to outwardly communicate, or brand and market, their product. Though, in many ways, the fundamentals of a green campaign are traditional, recent studies of developments in consumer expectations regarding quality, value and trust help cast a light on how green can advance a brand (Annice Laws, 2010). Some communication or advertising campaigns have the objective of developing or even transforming an organization's brand image. Brand image is at the heart of any organization's communication operations and activities, but for businesses it is often critical Communication campaigns that highlight an organization's commitment to sustainability may therefore be designed to embody and convey an image change. Undertaken as part of a corporate communication approach, they always have a more or less strategic impact on brand image. The arguments used to support a change in brand image can likewise be varied: new activities or new types of commitment, integration of environmental/social measures in production processes, development of a range of green products, etc. Lifestyle of Health and Sustainability (LOHAS) is one such green brand concept to explore new emerging eco-market. It has a strong focus on environmental Sustainability. Lifestyle of Health and Sustainability (LOHAS) is a new American concept which links Life-styles with Health, Hygiene and Sustainability aspects of the EcoMarket. LOHAS describes an integrated, rapidly growing market for goods and services that appeal to consumers whose sense of environmental and social responsibility influences their purchase decisions. The Natural Marketing Institute's (NMI) estimates the US LOHAS consumer market of products and services to be USD 209 billion - sold across all consumer segments (Cohen, 2007). Lifestyles of Health and Sustainability (LOHAS) is a demographic defining a particular market segment related to sustainable living, "green" ecological initiatives, and generally composed of a relatively upscale and well-educated 
population segment. The author Paul H. Ray, who coined the term 'Cultural Creatives' in his book by the same name, explains that "What you are seeing is a demand for products of equal quality that are also virtuous (Cortese, 2003; Everage, 2002). Researchers have reported a range of sizes of the LOHAS market segment. For example, World-Watch Institute of Washington reported that the LOHAS market segment in the year 2006 was estimated at $\$ 300$ billion, approximately $30 \%$ of the U.S. consumer market; and, a study by the Natural Marketing Institute showed that in 2007, 40 million Americans were included within the LOHAS demographics.

\subsection{Eco-Innovation to Promote Green Consumerism}

The environmental agenda has emerged gradually as an important policy issue over the last 45 years. During this period the environmental agenda and its impact on the economy has changed considerably. The last 10-15 years have seen a marked shift from a pure regulatory approach towards the slow rise of greening as a corporate issue. The greening of markets is now becoming apparent, particularly within the last couple of years as a consequence of the topical climate debate (Malaman, 1996, Hitchens, et al. 2002, 2003; Rand, 2000a, 2000b: Andersen, 2004, 2008; Ecotec 2002a\&b; Frondel, Horbach and Rennings, 2007; European Commission, 2002, 2004; OECD, 2008a, 2008b, 2009). As the environmental agenda has changed so has the notion of eco-innovation. It has been referred to hitherto as "environmental technologies" or "clean technologies". With a still more preventive and integrated policy approach to environmental issues the focus has changed from End-of Pipe/clean up technologies, to cleaner production processes, cleaner products to the broader eco-innovation or, quite popular lately, clean-tech business. In the Environmental Technology Action Plan (ETAP) of the EU Commission, a key policy initiative for the promotion of eco-innovation, environmental technologies are defined as: "all technologies whose use is less environmentally harmful than relevant alternatives. They include technologies to manage pollution (e.g. air pollution control, waste management), less polluting and less resource-intensive products and services (e.g. fuel cells) and ways to manage resources more efficiently (e.g. water supply, energy-saving technologies). Other more environmentally-sound techniques are process-integrated technologies in all sectors and soil remediation techniques" (EU Com, 2004).

For firms, a new perspective on consumer acceptance and perception to green products represent a great room of opportunities since green marketing is not purely altruistic, it can generate profits (Grant, 2008). The firm's challenge is to satisfy the consumers' "green" demand through proper design, production, sales and recycling of products. Add to that, strict environmental regulation to lower emission in the car industry, for instance, can be a challenge for many firms but also an opportunity to improve competitiveness by encouraging efficiency and innovation. Addressing environmental friendliness products, firms can 
differentiate themselves from competitors and to assure firm's competitive advantage, to enhance firm's corporate brand image, to show transparency and ethical values that can capture buyer's perceived credibility (Anderson, 2004 \& 2008), to develop green innovative and commercially viable products that meet environmental benefits and also to match customer interests. In brief green marketing seems to be a source of reputation, competitiveness and financial advantage (Worcester, 1993).

According to the United States Environmental Protection Agency, in 2007, the 2008 Prius is the most fuel-efficient car sold in the U.S. and beginning in 2009 the latest model became the most fuel-efficient automatic car. In UK, the Department for Transport reported that the latest Prius is the second least $\mathrm{CO}_{2}$-emitting vehicle on sale in the UK with $89 \mathrm{~g} / \mathrm{km}$. Green marketing strategies and tactics also might require changes in the marketing mix (product, price, place and promotion) and marketers must be conscious about such trends. Firms acquiring for instance an ISO 14000 certificate must produce goods with maximum recycled content and designed to have minimal environmental impact.

\section{Clean and Green Technologies: New Frontiers of Eco-Innovations}

The OECD (2011) defines 'Clean Technology' as: "Technologies that extract and use natural resources as efficiently as possible in all stages of their lives; that generate products with reduced or no potentially harmful components; that minimize releases to air, water and soil during fabrication and use of the product; and that produce durable products which can be recovered or recycled as far as possible; output is acbieved with as little energy input as is possible". In addition to this, it is also possible to identify cleaner technologies as a distinct approach that differs from more traditional end-of-pipe technologies, instead following a more integrated approach to reducing environmental pressures. This distinction is also made by the European Commission: "End-of-pipe solutions do not usually result in efficiency or productivity gains, therefore representing a pure cost to the firms. Cleaner technology on the other hand, improves process efficiency. Furthermore, cleaner technology usually reduces polluting emissions to all media instead of shunting them from one to the other". This definition highlights the attraction of cleaner technologies: they reduce production costs by improving process efficiencies. This means that investment in cleaner technologies occurs mainly through replacing or optimizing existing systems and equipment thus at the same time bringing about environmental benefits as well as efficiency gains, whereas end-of-pipe solutions represent additional investments in almost all cases. The use of cleaner technologies therefore triggers efficiency, thus presenting a means of implementing the concept of eco-efficiency.

\subsection{Clean Energy Technology Options}


Major changes from business as usual are needed to shift the energy sector onto a sustainable track. All major reports on climate change confirm that such a shift will require some mix of the following clean energy technologies: increased energy efficiency in power supply, demand, and transport; renewable energy-including wind, hydro, solar, and geothermal power and bio-fuels; nuclear energy; fuel switching to less carbon-intensive fuels (for example, from coal to natural gas); carbon capture and storage (CCS). In addition to these "hardware" technologies, "software" technologies including innovations in information technology, management, and planning (such as urban planning) can also play a critical role in mitigating climate change. Clean energy technologies differ substantially in their aggregate potential to reduce emissions (a function of the absolute availability of the resource and relative costs) and in terms of the stage of their development (such as whether the technologies have already been commercially proven or not).

\subsection{Green Technology: Promoting Environmental Technology Transfer}

The "green technology (GT)" is a broad term for more environmentally friendly solutions. GT for that matter can be used as environmental healing technology that reduces environmental damages created by the products and technologies for peoples' conveniences. It is believed that GT promises to augment farm profitability while reducing environmental degradation and conserving natural resources (http://www.ers.usda.gov/publications/aib752/aib752d.pdf). The risk associated with "dirty" technologies such as the petroleum products are alarmingly rising. The "clean" technologies as a result, are expected to provide lower risk alternatives. Data shows venture capitalists investing large amount of money into clean energy market and pursuing businesses facilitating renewable energy technologies that are energy efficient. One of United Nations Environmental Program's report states, in 2006, $\$ 2.9$ billion was invested in clean technologies (mostly in wind, solar and other low-carbon energy technologies), which was $80 \%$ higher over 2005 (http://www.wbcsd.org/plugins/DocSearch/details.asp). As climate change threat has spurred green investing, UNEP coins this trend as the "world's newest gold rush". GT covers a broad group of methods and materials for generating energy to non-toxic cleaning products. Although it is difficult to precisely define the areas that are covered by green technology, it can safely be said that GT helps addressing the emerging issues of sustainability because of the advancement in science and technology. This technology should meet the needs of society in ways that can continue indefinitely into the future without damaging or depleting natural resources. In short, GT is defined as the technology that meets present needs without compromising the ability of future generations to meet their own needs. In terms of the technology that can create products, which can be fully reclaimed or re-used, such cradle to grave cycle of manufacturing has successfully reduced waste and pollution by changing patterns of production and 
consumption. The innovations in technology have aroused interest in developing alternative fuels as a new means of generating energy and energy efficiency.

\subsection{Focus on Ecological Engineering and Eco-technologies}

New approaches must be developed and novel technological developments and engineering must function together in an integrated manner in order for social, economic and environmental benefits to be realized. Ecological engineering is an example of such an integrated approach. Ecological engineering practices can help conserve and restore the environment through the integration of engineering and ecological principles. An ecologically sound approach to engineering takes into account that nature responds systematically, continuously and cumulatively. Ecological engineering operates within the natural system rather than infringing on or overcoming it. To support such an approach, it is important to acquire knowledge and understanding about the dynamics of ecosystems and their particular vulnerabilities. Ecological engineering and related eco-technologies are dependent on the self-designing capabilities of ecosystems and nature. This focus on, and use of, biological species, communities, and ecosystems distinguishes ecological engineering and related eco-technologies from the more conventional engineering technology approaches which seldom consider integrative ecosystembased approaches. Ecological engineering involves identifying those biological systems that are most adaptable to human needs and those human needs that are most adaptable to existing ecosystems, while recognizing that it is counterproductive to eliminate or even disturb natural ecosystems unless absolutely necessary. Ecological engineering and eco-technology applications also emphasize understanding of the entire ecosystem rather than components of the system in isolation from one another. Decision support tools such as modelling and cost -benefit analysis are important, as ecosystem solutions cannot be determined by simply adding up the parts to make a whole.

\subsection{Creation of Business Potential of Clean Technologies}

The relation between environmental policies, clean technologies and their effects on the job market is subject to recurring discussion. For a long time these subjects have been perceived as conflicting and even contradictory, with business associations continuously quoting stricter environmental legislation as the reason for reduced revenues, job cuts or the move into countries with less strict environmental legislation. However, this perception has changed due to increasing evidence that the introduction of new environmental policies can actually contribute to job-creation. In the past years, discussions in the EU policy arena have increasingly addressed, highlighted and strengthened the relation between environmental protection and the generation of employment opportunities. Results of these discussions are expressed in several treaties, strategies and 
initiatives, including the Amsterdam Treaty, the Lisbon Strategy, the European Sustainable Development Strategy or the European Research Programs.

For each sector the study analyses the national backgrounds within the European Union and recent policy developments on the national and European level. Building on national experiences, relevant literature and studies, brief assessments are given about the job creation potential of each sector. While it is difficult to quantify the exact implications of the use of clean technologies on employment, the analysis of all sectors shows a general trend towards positive effects. In many cases job creation was triggered by funding initiatives from national or European authorities, as is demonstrated in the case of natural resource conservation and restoration. In addition, a conducive political framework, which includes the further development of certain environmental policies as well as the according advancement of employment policy are decisive for the job creation potential of clean technologies. Yet another issue is spill-over effects to other markets: Jobs created in the environmental sector frequently trigger the creation of jobs in other, related sectors up and downstream in the supply chain. Furthermore it should be pointed out that a large number of jobs depend on an intact environment, as for example in eco-tourism and sustainable agriculture, as the success of these industries is heavily contingent on efforts to conserve and protect natural resources. Finally, the development and stronger promotion of clean technologies through environmental legislation contributes to innovation and thus to increased (eco-) efficiency and competitiveness throughout the European Union.

\section{Eco-innovation - Case Studies on Eco-industrial Models}

Over past couple of decades, several organizations have attempted developing viable and eco-friendly business models on several demonstrative aspects of Eco-innovation. These models have been widely tested in challenging eco-systems with potential of application in real-life business environment. In many instances the associated parameters to test the eco-efficiency and systembased replicability and sustainability have also tried out with varying degrees of both success and failures. The following paragraphs illustrate some of the Ecoindustrial Business Models that have successfully demonstrated the effectiveness of eco-innovations in transforming business towards green growth with long-term sustainability.

\subsection{Green Business Model of Nordic Region}

The Green Business Model of Nordic Region: A Key to promote Sustainable growth, published by the Nordic Council of Ministers in October, 2010 as a 'Green Policy paper' of the region is a sound testimony as to how a Sustainable Business 
Model can be developed based on the core concept of Eco-Innovation (Nordic Council of Ministers, 2010). The Nordic countries are, like so many other countries, faced with a multiple set of challenges. The current economic crisis has severely impacted the economy in the Nordic countries and the Nordic companies. There is an increasing need for a more sustainable and low-carbon development, and a need for increasing innovation and improving competitiveness. These are some of the common challenges across the Nordic countries. The concept of green business models is a way of facing these challenges. Green business models involve the creation of new types of jobs, lower environmental impacts, and they are very promising platforms for innovation. Green business models come in various sizes and shapes; however, a common denominator is that the companies applying green business models can change their core business strategy from selling products to selling service systems which includes their products. These business models are known as Product Service Systems. Product Service Systems cover business models that are developed to provide the customer with a mix of products and services that are tailored for the customer's needs.

This Green Policy paper has explored various types of green business models that all to a certain extent build on the service system approach in order to cast light on the economical and environmental potentials of these models across the Nordic region. The key findings are that green business models have the potential to:

-generate solid business cases and jobs on a market that is expected to grow

-lead tosignificant lower environmental impacts

- serve as a catalyst for innovation in search for delivering the same or better services with the use of fewer resources

-support company branding - often both for the supplier and the customer

-increase motivation

Amongst workers, which againis a key component in attracting and sustaining the brightest minds now and in the future?

-become an international stronghold in the Nordic region

The majority of companies and experts interviewed for the 'Green Paper' pinpoint that in their view the economic and environmental potential for their specific business model or area of interest in the Nordic countries is significant. Green business models are, however, not very known and well disseminated in the Nordic countries. The Green Paper was only achieved through an aggregated Nordic assessment. For that reason, the companies and experts call on the politicians to support the green business approach in order to fast track their 
dissemination in the Nordic economy. The recommendations gathered from the companies and experts fall into six major categories spanning the different green business models that this Green Paper has explored. The following key recommendations can be highlighted:

-Increase awareness through case stories, documentation of effects, demonstration projects, guides etc. about green business models and the advantages they generate. The target group should be both the public and private business community

-Support the sales position of the suppliers of green business models with tools and arguments that clarify the potential directed at the relevant levels and access points in the customer's organization including high level management

-Promote the potential benefits and business opportunities of Green Business models for private and public financial institutions

-Promote the use of green business models in public procurement and regulation

-Develop common Nordic standard contract paradigms for green business models

Both the EU Commission and the US Environmental Protection Agency have recently undertaken respective desk studies on green business models. However, this Green Paper marks the first project which focuses on the Nordic region. The Green Paper provides a first step in identifying and describing green business models in the Nordic region and in exploring their economic and environmental potential. However, it should be underlined that the design and implementation of policies to foster and strengthen the determinants of green business models lies outside the scope of this Green Paper.

\subsection{The Luxembourg Eco-Innovation Cluster}

Luxembourg hosts a thriving eco-innovation sector. There are numerous ecocompanies in the country, working mainly in the field of eco-construction, renewable energy, waste management, water and electro- mobility, supported by numerous public agencies and research organizations. The goal of eco-innovation is to reduce the environmental impact of processes, products and services. Luxembourg's research activities in environmental technologies focus on environmental management, life-cycle assessment, clean technologies and process engineering, environmental modelling as well as the sustainable management of aquatic and terrestrial ecosystems. The take-up of green technologies is empowered by an ambitious Government action plan, which has recently been adopted in order to stimulate the production of eco-technology products, the 
management of natural resources and changes in the design and development of production and consumption systems, in order to make them cleaner and more resource efficient (eco-construction, eco-design, environmental regulations of processes, recycling materials, etc.). Another priority is to support research and development in the environmental technologies field, thereby leading to greater sustainability and economic diversification. The Luxembourg Eco-Innovation Cluster is a network that supports the various actors of the eco-innovation sector in Luxembourg with the goal of creating and developing new and sustainable business opportunities through collaborative R\&D and innovation projects.

The Luxembourg Eco-Innovation Cluster comprises companies, research institutes and public organizations involved in the field of eco-technologies. Due to this unique mix of competences, the Luxembourg Eco-Innovation Cluster provides support for the development of collaborative project ideas, the identification of potential business partners and the search for suitable funding in order to empower the development of the eco-technologies sector in Luxembourg and to increase the uptake of "green technologies". The Luxembourg Eco-Innovation Cluster comprises companies, research institutes and public organizations involved in the field of eco-technologies. Due to this unique mix of competences, the Luxembourg Eco-Innovation Cluster provides support for the development of collaborative project ideas, the identification of potential business partners and the search for suitable funding in order to empower the development of the eco-technologies sector in Luxembourg and to increase the uptake of "green technologies".

\subsection{Eco-Industrial Parks}

The concept of an eco-industrial park is a sector of industrial ecology, which draws analogies from natural ecosystems to human industrial systems. The most important viewpoints are closing the material flows and energy cascading. An ecoindustrial park is clearly defined areas where materials, energy and information exchange occur between various companies and actors. Implementing an ecoindustrial park can bring environmental, social and economic benefits. Material and energy exchanges between different actors in the area can evolve by themselves over a long period of time (e.g. Kalundborg, Denmark). On the other hand, eco-industrial parks can be intentionally planned for a totally new area or around already existing operations. An industrial park is also defined as "a large tract of land, sub-divided and developed for the use of several firms simultaneously, distinguished by its shareable infrastructure and close proximity of firms" (Peddle, 1993). Types and synonyms of industrial parks include industrial estates, industrial districts, export processing zones, industrial clusters, business 
parks, office parks, science and research parks, and bio-technology parks. In 1995, Co 'te' and Hall (1995) proposed this definition: "An eco-industrial park is an industrial system which conserves natural and economic resources; reduces production, material, energy, insurance and treatments costs and liabilities; improves operating efficiency, quality, worker health and public image; and provides opportunities for income generation from use and sale of wasted materials". Yet another definition was put forward by Lowe et al. (1995): “An ecoindustrial park is a community of manufacturing and service businesses seeking enhanced environmental and economic performance through collaboration in managing environmental and resources issues including energy, water and materials. By working together, the community of businesses seeks a collective benefit that is greater than the sum of the individual benefits each company would have realized if it optimized its individual interests".

An excellent definition for eco-industrial park has been developed in the USA through the President's Council on Sustainable Development (PCSD): "A community of business that co-operate with each other and with the local community to efficiently share resources (information, materials, water, energy, infrastructure and natural habitat), leading to economic gains, gains in the environmental quality and equitable enhancement of human resources for the business and local community. In twelve years the Eco-industrial Park (EIP) has evolved from a visionary concept to hundreds of projects seeking to implement the concept around the world. This rapid dissemination has naturally led to differing understandings of what the term means. On the one hand, the US-EPA, the US President's Commission on Sustainable Development, a Handbook this author produced for Asian Development Bank and a number of major universities has tended to agree on a basic broad systems definition. In China the State EPA has identified the EIP as one of the important tools for realizing the Circular Economy. However, many specific pilot project plans have focused on company exchanges or "eco-chains" rather than using the full systems definition. Benefits of eco-innovation parks Industrial parks plays a central role in natural resource consumption and environmental issues for every country analyzed in this survey. Industrial parks can have major consequences for the system as a whole, impacting several material/energy flows.

\subsection{Eco-Industrial Clusters and Zero Emissions Effort}

The term "industrial cluster" refers to more generalized, geographically neutral efforts that seek to develop the "industrial symbiosis" concept. Industrial clustering involves physical exchange of materials, energy, water and by-products (Mihashi, 1998). Clustering or symbiosis can take place "within a facility or firm, among firms co-located in a defined eco-industrial park, among local firms that 
are not co-located, or among firms organized "virtually" across a broader region" (Chertow, 1999). The ZERI foundation provides the following definition of zero emissions: "Zero Emissions envisages all industrial inputs being used in the final products or converted into value-added inputs for other industries or processes. In this way, industries will reorganize into "clusters" such that each industry's waste by-products are fully matched with others' input requirements, and the integrated whole produces no waste of any kind" (http://www.zeri.org/theory.htm). In Japan, this concept has often been used analogously with the widely accepted concept of Zero Defects (Total Quality Management) and Zero Inventory (Just in Time Production), which helps explain its popularity and prevalence as a concept. Although zero emissions is sometimes perceived as a special arrangement in Japan, it is a conceptual tool for the development of industrial symbiosis that can take place within a firm (reuse and recycle) or as a regional and inter-regional by-product exchange arrangement. Most of the zero emissions efforts in Japan are no different from the attempt to promote symbiotic linkage with the ultimate goal of zero waste. Often, zero emissions can be found in an industrial cluster with an anchor industry such as a beer brewery or electronics appliance plant. Yet, it is still worthwhile to examine these projects, considering their popularity and increasing number. For instance, 38 plants belonging to five beer and alcoholic beverage companies achieved zero waste by 1999 , and 10 companies are on their way to accomplish zero waste in the near future.

\subsection{Eco-Industry's Business Potential for Job creation}

The green industry focuses on making a profit while having a negligible (or even a beneficial) impact on the environment. Leaders make sustainability a key consideration in decision-making throughout the organization as they work to minimize both use and production of harmful chemicals, excess materials, and waste byproducts in the delivery of their goods and services. Recognizing the importance of our planet's dwindling natural resources, the green industry seeks to meet the demands of today without compromising the needs of tomorrow. It is difficult exactly to define the "eco-industry", and therefore also its growth and export potential.The environmental industry comprises firms which provide goods and services for both environmental protection and resources management (e.g. waste recycling, renewable energy supply and water supply). Eco-industries have been defined according to the definition contained in "The Environmental Goods and Services Industry - Manual for Data Collection and Analysis" (OECD/Eurostat, 2005). This defines eco-industries as: "Activities which produce goods and services to measure, prevent, limit, minimize or correct environmental damage to water, air and soil, as well as problems related to waste, noise and eco-systems. This includes cleaner 
technologies, products and services that reduce environmental risk and minimize pollution and resource use".

A recent EU study has made estimation on the situation in the EU-15 and the Candidate Countries (ECOTEC, 20002 a \&b). The report says that EU ecoindustries is a strong and diverse export sector, and is major global player alongside the USA and Japan. The global eco-industry market is estimated at around $550 \mathrm{Bn}$ euros in 1999. This means the EU has approximately one third of the overall market (183 $\mathrm{Bn}$ euros), equal to the USA. The Japanese market is estimated to be worth about $84 \mathrm{Bn}$ euros. The Canadian market is the next most significant at $36 \mathrm{Bn}$ Euros. The overall turn-Over (Million Euros) of the EcoIndustries in EU Region during 1999 is given in Table 4.

Table 4: Turn-Over (Million Euros) of Eco-Industries in EU Region, 1999 Scenario 


\begin{tabular}{l|c|c|c|c|c|c} 
Country & $\begin{array}{c}\text { Pollution } \\
\text { Management }\end{array}$ & $\mathbf{\%}$ & $\begin{array}{c}\text { Resources } \\
\text { Management }\end{array}$ & $\mathbf{\%}$ & $\begin{array}{c}\text { Total } \\
\text { Turnover }\end{array}$ & $\%$ \\
\hline Austria & 8,270 & 7 & 620 & 1 & 8,900 & 5 \\
\hline Belgium & 2,400 & 2 & 2,380 & 4 & 4,770 & 3 \\
\hline Denmark & 5,400 & 4 & 1,220 & 2 & 6,630 & 4 \\
\hline Finland & 1,790 & 1 & 310 & 1 & 2,100 & 1 \\
\hline France & 22,330 & 18 & 15,660 & 28 & 37,990 & 21 \\
\hline Germany & 41,190 & 32 & 15,510 & 28 & 56,710 & 31 \\
\hline Greece & 1,040 & 1 & 850 & 2 & 1,900 & 1 \\
\hline Ireland & 530 & 0.4 & 250 & 0.5 & 790 & 0.4 \\
\hline Italy & 10,700 & 8 & 5,280 & 9 & 15,980 & 9 \\
\hline Luxembourg & 160 & 0.1 & 110 & 0.2 & 280 & 0.2 \\
\hline Netherlands & 7,170 & 6 & 2,440 & 4 & 9,610 & 5 \\
\hline Portugal & 920 & 1 & 830 & 1 & 1,750 & 1 \\
\hline Spain & 5,530 & 4 & 2,510 & 4 & 8,030 & 4 \\
\hline Sweden & 2,620 & 2 & 690 & 1 & 3,310 & 2 \\
\hline UK & 17,090 & 13 & 7,390 & 13 & 24,470 & 13 \\
\hline EU-15 & $\mathbf{1 2 7 , 1 4 0}$ & $\mathbf{1 0 0}$ & $\mathbf{5 6 , 0 7 0}$ & $\mathbf{1 0 0}$ & $\mathbf{1 8 3 , 2 2 0}$ & $\mathbf{1 0 0}$ \\
\hline
\end{tabular}

Source: ECOTEC (2002a)

North America remains the EU's biggest export market and has shown significant growth, while the Candidate Countries are becoming increasingly important export markets, in particular for EU Member States with close historical trading relationships to that region. The favoured method of EU company penetration into this market is through setting up a joint venture with domestic companies. EU companies are amongst the world leaders in developing new renewable energy technologies, both for domestic markets and worldwide. The strong and expanding domestic markets provide the basis for many EU companies to be active in worldwide markets. For example, the EU is the largest market for wind energy developments, with $75 \%$ of the total world installed capacity of $18.5 \mathrm{GW}$. According to the ECOTEC study (2202a), direct employment in the EU in ecoindustries amounts to over 2 million (FTE) jobs in 1999. Employment levels for the wider environmental industry sector are significantly larger than the core ecoindustry (i.e. pollution management) definitions used in the past. A high-end estimate of environmental employment is around 4 million jobs, using various procedures to give more realistic coverage and including the use of 'multipliers', which try to build in the indirect effects of environmental expenditure (ECOTEC, 2002a). Environmental sector employment accounts for on average 1.3\% of total paid employment in the EU-15, although it is higher in some countries (e.g. Austria, Denmark, and France). For every $1 \mathrm{Bn}$ euro of investment in environmental goods and services there is another 1.6 $\mathrm{Bn}$ euro generated in 
operating expenditure and the generation of 30,000 direct jobs (ECOTEC, 2002b). According to a study by the Swiss Federal Statistical Office, Switzerland employed approximately 50'000 people in the eco-industrial sector in 1998, equivalent to approximately $1,3 \%$ of all employees that year. This figure comprises $15^{\prime} 000$ employees in fully eco-industrial activities and 35'000 employees in partially eco-industrial activities. In the fully eco-industrial sector, $77 \%$ of the employees were active in sewage purification, waste disposal and other disposal and $20 \%$ and $3 \%$ respectively in the areas of recovery and preparation for recycling and wholesale of scrap and waste material. Of the employees in the fully eco-industrial sectors, $6 \%$ were women and $94 \%$ men, of which only $53 \%$ of the women and $92 \%$ of the men were employed on a full-time basis.

A study by GHK, IEEP and Cambridge Econometrics (2007) on 'Links between the environment, economy and jobs', looked not just at the direct jobs captured in the eco-industry concept, but also used multiplier effects to calculate the 'indirect' jobs created and jobs dependent on a good environment within for example ecotourism and organic farming. According to the these studies, the eco-industry "produces" goods and services to measure, prevent, limit, minimize or correct environmental damage to water, air and soil, as well as problems related to waste, noise and eco-systems. This includes technologies, products and services that reduce environmental risk and minimize pollution and resources. The sectors fall into two general categories, pollution management and resource management. The update of the GHK study shows how a broader definition of jobs related to the environment increases the numbers. If one uses the broader definition, some 19 million jobs in Europe are related to the environment which represents some $5 \%$ of the total working population (2010 figures).

Green industries currently account for a 15\% share (approx. USD 430 billion) of the world's economic stimulus packages. In the midst of the crisis, Germany has injected some EUR 80 billion into the economy, about 13\% of which is set aside for climate and environmental protection activities. Compared to the international community, that is a fairly modest sum. South Korea, for example, plans to pump around USD 36 billion - fully $80 \%$ of its overall stimulus package - into energy efficiency, renewable energy and water pollution control over the next four years. In absolute terms, China is spending most (in the context of economic stimulus) to protect the environment and the climate: more than USD 220 billion - twice as much as the USA. As early as 2013, the market for environmental technologies including renewable energy should be worth USD 1 trillion in the People's Republic. The true extent of such potential is revealed by a study commissioned by the US chambers of foreign trade. In collaboration with Roland Berger Strategy Consultants, they asked 300 companies in the US green-tech industry including the US subsidiaries of a number of German firms - about their 
expectations for the future. Some $34 \%$ of the US companies said that they expect their revenues to grow by more than $10 \%$ within the next year and by a further $51 \%$ in the next five years. The mood among the subsidiaries of German firms in the USA was even more upbeat: 38\% expect at least 10\% higher revenues in the next year and a further $60 \%$ increase over the next five years. The labor market will also benefit: fully $87 \%$ of companies in the study plan to quickly create new jobs.

\section{Entrepreneurship and Eco-Innovation}

Green-technology entrepreneurs using new paradigms are creating radical and disruptive vehicle eco-innovations. This aspect focuses on green-technology entrepreneurs and how their innovations, largely based on new computer, electronic and battery competencies, are challenging large legacy automobile manufacturers' traditional competencies. Dramatic external environment shifts produced market discontinuities and opportunities for multiple green-technology new venture entrepreneurs to emerge from outside the vehicle industry, spurring legacy corporation green technologies. Six critical external environmental determinants are facilitating new eco-technology innovations: three push determinants-technology, U.S. federal government and U.S. state/local government; and three pull determinants-demonstrated corporate entrepreneurial success, market and plug-in hybrid and electric infrastructure. Finally, this paper highlights that entrepreneurial ventures often incorporate multiple strategic alliance types in their initial stages and path-dependent growth strategies. Tesla Motors, Inc., with its introduction of a radical and potentially disruptive green technology, best illustrates the use of strategic partnerships by new venture green-technology entrepreneurs.

Schumpeter (1911) linked entrepreneurship and innovation concepts by adding innovation as one of the central dimensions of entrepreneurship. Entrepreneurs were seen as creating new products, processes, markets, factor and organization innovations, as well as playing a key role in overall economic development. Entrepreneurship also has been viewed as the ability to see opportunities in the market earlier than others, often by focusing on "gap-filling" opportunities (Leibenstein, 1968). Shane and Venkataraman (2000) also conceptualize entrepreneurship as involving "the nexus of two phenomena: the presence of lucrative opportunities and the presence of enterprising individuals." Entrepreneurial innovation and opportunity-seeking often focus on disruptive or radical innovations that challenge dominant firms. 
Corporate entrepreneurship is seen as critical for existing corporations to successfully create, develop and execute new ventures that renew their product and technology portfolios as their existing products age and markets mature (Lumpkin and Dress, 2001 \& 2004; Lumpkin and Lichtenstein, 2005; Luchsinger and Bagby, 1987,). Corporate entrepreneurship has also been labeled as "intrapreneuring" (Pinchot, 1985) or "entrepreneurship," where existing corporations build new innovative businesses from within using an entrepreneurial approach. Existing corporations, including many large legacy automobile manufacturers, face multiple challenges in adopting corporate entrepreneurship or an entrepreneurial orientation. New corporate ventures tend to be located at the edges or within the seams between existing businesses, require different business and financial models and require very different cultures (Garvin and Levesque, 2006). Miller (1983) presented three dimensions for building successful corporate entrepreneurship — innovativeness, risk-taking and proactiveness - and Dess and Lumpkin (2005) in their "entrepreneurial orientation" framework added two additional dimensions - competitive aggressiveness and autonomy. Dess and Lumpkin's (2005) framework for effective corporate entrepreneurship provides insights into the critical role of green-technology vehicle corporate entrepreneurship within larger legacy corporations. The entrepreneurial orientation framework is useful in suggesting how Toyota's green-technology corporate entrepreneurship served Toyota well and acted as another significant catalyst for the emergence of new start-up greentechnology vehicle entrepreneurial ventures.

\subsection{Green-Technology \& Entrepreneurship Strategic Alliances - Pathways to Green Growth}

Since the seventies, the number of inter-organizational alliances (e.g., joint ventures, $\mathrm{R} \& \mathrm{D}$ collaborations, co-marketing agreements) has increased exponentially. More and more, firms tend to call on external partners to meet the increasing uncertainty in the (inter) national business world, resulting in a growing pressure on margins, higher quality standards, advanced customer demands and fast changes in technological developments. The use of collaboration has become particularly acute in capital- and knowledge-intensive business sectors. Product and technological complexity, and the shortening of the innovation cycles have made companies increasingly dependent on external parties in their product development, leading to the so-called open innovation model (Chesbrough, 2002, 2003). Entrepreneurial alliances, which in the present case include greentechnology entrepreneurial alliances, are significant and "play central roles in new models of competition, innovation and organization" (Reuer, Ariño and Olk, 2011). Firms increasingly use collaborative paradigms that look beyond their own 
boundaries to identify, develop and maintain sustainable competitive advantage and to develop sophisticated, effective and flexible strategies.

Strategic alliances have increased in number and importance and are now a core strategic offensive and/or defensive competitive element in many U.S. and E.U. industries, including green-technology entrepreneurial firms (Das and Teng, 2000, 2002; Beaume and Midler, 2009). Strategic alliances and networks of alliances are modifying the competitive paradigm, from firm-to-firm competition to alliancebased network-to-network competition, in many U.S. and international markets. The growth in alliance-based innovation and competition is exemplified by the green-technology vehicle market, especially the new green-technology entrepreneurial entrants (Beaume and Midler, 2009). By fundamentally shifting the customer value proposition, these disruptive technology innovations can significantly impact the competitive advantages of a single firm (Aggeri, Elmquist and Pohl, 2009). Examples of technology shifting products from multiple industries are hybrid vehicles and plug-in hybrid/electric vehicles; online travel auctions, media and publishing delivery, banking and investing; mobile smart phones; digital television; Apple's iPod, iPhone and iPad; RIM's Blackberry; pharmaceutical advances, etc.

New green-technology ventures suffer from many of the same challenges as other entrepreneurial ventures due to their "liability of newness." This "liability of newness" might take the form of a lack of resources and all the required competencies; potential lack of all needed technologies; frequent lack of proven markets; and potential lack of legitimacy, access or relationships with key stakeholder groups; such as suppliers, customers, financial institutions, etc. (Reuer, Ariño and Olk, 2011). Entrepreneurial new venture green-technology firms, as well as corporate entrepreneurial green-technology ventures, frequently have substantial funding challenges moving from development to full-scale production. Some entrepreneurial green-technology companies operate in multiple industry segments. In addition, there are numerous other entrepreneurial new ventures as well as large companies that are also active in the various industry segments.

\section{Economic Impact Assessment of Eco-Innovation}

From a methodological point of view, evaluation processes can benefit from a combined use of quantitative and qualitative indicators that can monitor and assess the progress of the project, its compliance with initially designed objectives and its impacts on various levels, ranging from the people involved in the project to the broad socioeconomic environment at regional, national and even European levels. For example, quantitative evaluation methods combined 
with performance indicators make it possible to capture the dynamics involved in science and technology ( $\& \& \mathrm{~T}$ ), which provides good estimates of the outputs and impacts of public intervention. Policy makers could make use of these impact estimates to legitimize and support policy intervention. Qualitative evaluation methods offer more detailed insights on the multiple effects of policy intervention, which might help improving the processes and instruments of S\&T policies (European Commission, 2002). The somewhat broadly defined term "eco-innovation" conceals the possible target conflicts and key issues that have to weighed up and considered in connection with the "responsible use of natural resources".

The European Commission also fails to explain both why eco-innovations should be given more support than other innovations (e.g. the health sector) and why exactly it thinks eco-innovations are being marketed too slowly. The task of politics is to design the framework conditions allowing for innovation activities in companies. In the EU, not all Member States are equally successful in doing so, as can be seen in the statistics for patent registration. In 2009, an average of 119 patents per 1 million inhabitants was registered with the European patent registry. In Germany there were about 295 patents and in Sweden there were even 332, whereas it was only 2 in Romania and about 1 in Bulgaria. An innovation-friendly environment is good for the business location Europe. A high political impact on the form of innovation activities increases the quality of the business location for the companies of those sectors which are in line with the political criteria; that of others is reduced, since they too must pay the price of increased public expenses through taxes.

\subsection{Legal Assessment Competency}

The EU may adopt measures to protect the environment and for a rational use of natural resources (Art. 191 (1) TFEU). Moreover, it may contribute to innovation research and technological development, whereby it may only act in a supportive manner regarding national measures (Art. 173 (3) in conjunction with Art. 2 (5) and Art. 6 TFEU). The currently foreseeable eco-innovation plans by the Commission do not exceed these limits. Where the targets of measures cannot be achieved by Member States but need e.g. EU-wide coordination, EU action might be in line with the principle of subsidiarity (Art. 5 (3) TEC). The Commission's definition of the term "eco-innovation" conceals the key target conflicts and issues that have to be considered for the "responsible use" of natural resources. The Commission fails to explain both why it thinks eco-innovation is being marketed too slowly and why eco-innovation should be given more support than other forms of innovation. As the impact of innovation is hardly foreseeable, it is 
a mistake to promote innovative behaviour only in politically defined areas. Product labelling can raise awareness of environmental characteristics. The planned further development of environmental legislation and the development of product standards and performance targets carry with them the threat of serious intervention into production processes.

\subsection{Goals for Environmental Impacts and Sustainability Indicators}

Environmental impacts are among the most thoroughly assessed issues in each study of new business models. Some authors suggest a structured methodology for the evaluation of environmental benefits of each type of business model. Tukker (2004) and Tukker and Tischner (2006) used the "sustainable design rules approach" in evaluating each type of PSS model against a set of impact reduction mechanisms. The finding was that most PSS types result in environmental improvements but the level of improvement is rather modest. Improvements tend to be incremental to average at best and are "mainly related to economic efficiency gains and hence might be less relevant for human-resource intensive systems". Creating new value for civil society requires the casting of goals with a definite time frame. To the extent that value creation requires natural resources, the goals have to respect the laws of nature. Specifics, including policy instruments, for protecting nature's services may vary for differing geographic and geological conditions. In Germany, for instance, it means a Factor 10 increase, requiring a yearly absolute improvement in resource productivity of almost 5\%, starting now. In the United States, the resource use would have to decline by about a factor of 15, and in Finland higher than that. If the dematerializations indicated above for industrialized countries were achieved, they would allow developing countries to increase their use of natural resources, for improving their quality of life without jeopardizing the overall goal of global sustainability.

\subsection{Alignment with Economic Policy}

No incentives or policies currently exist for a sufficiently resource-efficient economy: the key flaw of the present mainstream economic model is its lack of incentives for increasing the productivity of natural resources. For this shift, a strong preference seems to be emerging for economic instruments, such as environmental tax reform and market-creation policies, including tradable permits. Instead of value-added taxation, for instance, it may be more efficient to tax natural resource's use before goods for final use have been produced, while lowering taxation of labour accordingly. Preference to dematerialized goods, infrastructures, and services, could give the manufacturing sector a powerful 
incentive to increase resource productivity. In Germany, this may be a particularly attractive option as it has been shown that some $20 \%$ of resource-input production costs could be saved on average without negatively affecting outputs. Agreement has also emerged in civil society that improving education and training on all levels, as well as enhancing the public availability of relevant information, will play a central role as part of a progressive strategy. As new technical and societal developments tend to require ten to twenty years for taking hold, dematerialization must commence immediately A single country cannot bring about the needed changes, but Europe with its historic experience, economic power, and technical skills has a realistic chance to lead humankind to a more promising future.

\subsection{Role of Enabling Technologies and Infrastructure}

The success of radical innovation and of new business models depends on the enabling environment. In their examination on how to advance systemic ecoinnovation, Johnson and Suskewitcz (2009) focus on the role of enabling technologies to help create systemic changes. For example, the emergence of railways was catalyzed by the invention of steam engines; the creation of microprocessors helped launch the information age. The real effect of those enabling technologies was felt only after new systems (railways, ICT infrastructure) had evolved around them. Most case studies point to the importance of enabling technologies and supporting infrastructures, which are often a key success factor behind the introduction of certain new business models.

The literature particularly highlights the role of ICTs that allows inconveniences for customers to be Minimized and the efficiency of the system to be maximized. The Vélib bicycle sharing system in Paris, for example, is supported by an internet map showing real-time data on the availability of bicycles and parking spaces (OECD, 2010a). The software used in electric vehicles, which was designed and developed by Israel's Better Place, provides the driver with complete information by displaying the energy level in the battery, locating the nearest battery recharging and swapping facilities, and allowing the driver to handle their booking, parking and charging spots conveniently (Meenakshisundaram and Shankar, 2010). Similarly, many service-oriented business models such as ESCO and videoconferencing services are very much dependent on ICTs which enable monitoring and control of data and information (EPA, 2009). Availability of supporting physical infrastructures is also often an important factor for eco-innovative solutions. The success of the biogas-based transport system in Linkoping, Sweden owed in a large degree to the specifically designed refuelling stations both for public buses and private cars (Martin, 2009). The Better Place electric car sharing system developed automated battery swapping facilities which can replace 
depleted batteries with charged batteries within three minutes without drivers getting out of the car (Meenakshisundaram and Shankar, 2010).

\section{Measurement Mechanisms of Eco-innovation Impact}

Eco-innovation impact needs to be measured to assess its effectiveness in economic, environmental and sustainability terms. The following explains the benefits as well as key challenges linked to measurement of Eco-innovation impacts.

\subsection{Benefits of Measuring Eco-innovation}

Measuring eco-innovation helps to evaluate progress within various categories of eco-innovation; to assess which nations are leading; how much progress nations are making to decoupling growth from environmental degradation, and it allows for an analysis of the drivers of eco-innovation and of the economic and environmental consequences. The benefits of measuring eco-innovation can be described as five-fold:

- Helping policy makers to understand, analyze, and benchmark the overall trend of eco-innovation activity (increasing, decreasing, transitions in the nature of ecoinnovation such as from end-of-pipe towards cleaner production and increased recycling and reuse); as well as trends in specific product categories (such as wind turbines).

- Helping policy makers to identify drivers and barriers to eco-innovation. This information can inform the design of effective policies and framework conditions such as pollution taxes.

- Raising awareness of eco-innovation among stakeholders and encourage companies to increase eco-innovation efforts based on an analysis of the benefits for companies, sectors and nations.

- Helping society to decouple economic growth from environmental degradation.

- Making consumers aware of differences in the environmental consequences of products and life styles.

It is important to note that thus far eco-innovation has helped to achieve a relative decoupling, with emissions levels falling relative to economic growth, but increasing in an absolute sense in almost all nations for many pollutants. What is needed is an absolute decoupling. This shows that there is an important issue of scale. One should look not only at reductions achieved at the micro level thanks to the adoption of eco-innovation but also look at economic growth and rebound effects from cost-saving eco-innovation. For instance, savings from reduced consumption of material inputs frees up capital and income for additional 
consumption of 7 different commodities. The net effect can be no decrease in material use and associated environmental impacts at all. Aspects to be measured include: Nature of eco-innovation and scale of use; Drivers \& barriers of ecoinnovation and Effects of eco-innovation.

Different attempts have been made to construct a classification system for ecoinnovations. From a wider system point of view, eco-innovations may be categorized as sustaining and disruptive innovations. An example of a sustaining innovation is the catalytic converter, which supported the continued use of the internal combustion engine. An example of a disruptive innovation is the battery electric vehicle (Christensen, 1997). There exist several classifications of ecoinnovation. A synthesis of what exists is needed. One attempt at synthesis is made in the MEI project which created a classification based on the purpose or objective of the innovation. It makes a distinction between environmental technologies, organizational innovations for the environment, product and service innovations that offer environmental benefits, and green system innovation.

In a special project for the OECD of 3,100 establishments in seven industrialized countries, projects to introduce environmental technology were assigned to end of pipe technologies or to cleaner production technologies. The latter accounted for between 57.5\% (Germany) and 86.5\% (Japan) of the total, as shown in Figure 4. For the seven countries together, more than $75 \%$ of the respondents reported that the majority of their projects to adopt environmental technologies were for cleaner production technologies. These results also indicate that end-of-pipe technologies are typically introduced to cope with regulatory compliance, while the implementation of cleaner production technologies is driven by the potential for increasing manufacturing efficiency and reducing costs of operations.

Figure 4: Types of environmental technologies implemented in 3,100 establishments (facilities) in seven OECD countries (In percent) 

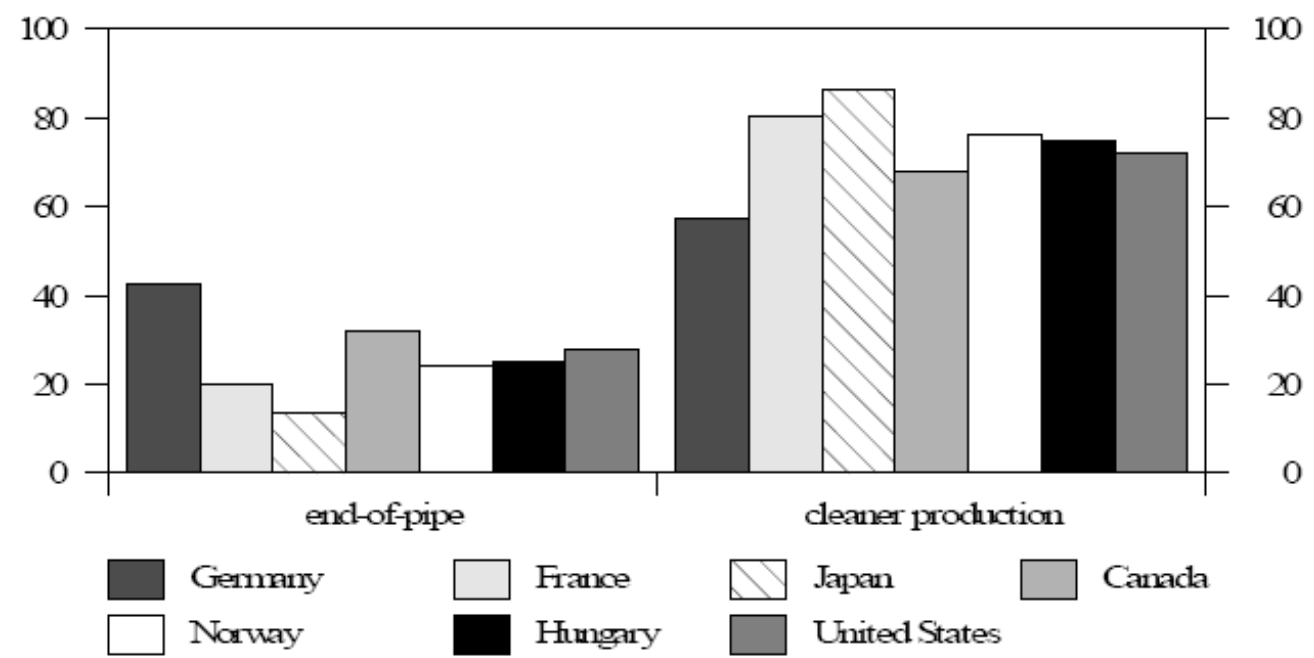

Source: Frondel et al. $(2004 ; 2007)$

10.2. Key Challenges of Measuring Eco-innovation

Appropriate indicators should be developed in order to better analyze the development of eco-innovation including evolution of environmental technologies' markets. They should also measure the progress made in implementing the Environment Technology Action Plan. Currently, the field of eco-innovation lacks statistics and indicators. The challenge consists very much of trying to combine the two important frames in eco-innovation development: the innovation chain or system; and environment technology seen in a wider perspective. However, the methods and perspectives applied in innovation indicators are quite different from environmental indicators. Eco-innovation indicators are response-indicators measuring societal progress, supplementing other indicators. Also, eco-innovation indicator development is at an early stage, which means the development must be underpinned by research, conceptual development, surveys and assessments. Developing and refining current approaches to measuring eco innovation is a necessity for evidence based policy development. Development of public policy, as well as public-private partnership based, initiatives in various fields starting with innovation but encompassing industrial, environmental, regional and urban development, transport, etc. need a sounder and more comprehensive knowledge of the potential influence they can exert on the incentive for enterprises to orientate their innovation activities in line with the eco-innovation concept. 
With the recently launched European Environmental Technologies Action Plan (ETAP) new policy signals were sent in the simultaneous pursuit of environmental and competitiveness goals. For the first time environmental and innovation policies were sought aligned. However, the ETAP need as yet to be unfolded. Indicators could play an important role in operationalizing targets and creating stronger political rigour. The report on the implementation of ETAP adopted by the Commission in January 2005 calls for the development of indicators on ecoefficiency and on the market penetration of environmental technologies. An extract of the report conclusions is the following: "Appropriate indicators should be developed in order to better analyze the development of eco-innovation and evolution of environmental technologies' markets. They should measure both market developments and the performance of EU industry in the market. They should also measure the progress made in implementing the Action Plan as well as the eco-efficiency of the EU economy. They should build on the work done by the Commission (Eurostat, 2007) in the field of environmental accounting and of eco-efficiency indicators."

The EEA has a special focus on monitoring, assessment and reporting. Contributing to the development of eco-innovation indicators could be an important way for EEA to support the ETAP. The EEA has therefore taken the initiative to produce this scoping study on the prospects of developing ecoinnovation indicators. The report should function as a starting platform for in depth work on developing ETAP indicators, as well as providing inputs for future EEA Signals Report. Currently, the field of eco-innovation lacks statistics and indicators. The challenge consists very much of trying to align two well-developed but different set of indicator bodies, the environmental and the innovation set. A large number of composite indicators are regularly published by many intergovernmental, international and national institutions. Some of these composite indicators are built on sets of indicators, some of which are relevant to eco-innovation and environmental technologies. Similarly, in its most recent report on monitoring EU sustainable development strategy, EUROSTAT (2007) lists indicator on 'eco-innovations' among a list of indicators 'to be developed'. The major conceptual and operational challenges in measuring eco-innovation include:

- agreeing on selected key eco-innovation indicators on the micro level, taking into account the whole-life-cycle approach and wider impacts in depicting eco-efficiency aspects of eco-innovations;

- clarifying different analytical levels of eco-innovation analysis and developing insightful data aggregation methods; and

- establishing operational approaches to link different levels of analyzing eco-innovations to understand their systemic effects and their relation to 
other key indicators, most notably to these measuring economic growth and sustainable development.

Eco-innovation research and data collection should not be limited to products from the environmental goods and services sector or to environmentally motivated innovations but should cover all innovations with an environmental benefit, with research inquiring into the nature of the benefits and motivations for it. Attention should be broadened to include innovation in or oriented towards resource use, energy efficiency, greenhouse gas reduction, waste minimization, reuse and recycling, new materials and eco-design. The drivers are related but different and the patterns of eco-innovation activity are likely to be different as well. One area for future research (besides measuring what companies do in terms of eco-innovation) is the macro-effects of eco-innovation, to complement studies on the micro-effects. Measuring the greenness of national systems of innovation (green taxes, education, collaboration, venture capital, subsidy schemes, environmental standards, education relevant to green issues) constitutes another important avenue for research. It would be of interest to develop a scoreboard for eco-innovation.

\subsection{The Eco-Innovation Scoreboard}

The Eco-Innovation Scoreboard (Eco-IS) developed by the EIO is the first tool to assess and illustrate eco-innovation performance across the $27 \mathrm{EU}$ Member States. The Eco-IS shows how well individual Member States perform in different dimensions of eco-innovation compared to the EU average and presents their strengths and weaknesses. Thereby, the Eco-IS complements other measurement approaches of innovativeness of the $\mathrm{EU}$ and $\mathrm{EU}$ countries, notably the Innovation Scoreboards, and aims to promote a holistic view on economic, environmental and social performance. The Eco-IS contains indicators grouped into five areas: eco-innovation inputs, eco-innovation activities, eco-innovation outputs, environmental outcomes and socio-economic outcomes. The 2011 version of the Eco-IS, which is updated on an annual basis, is the second published version and differs from the first version in number and types of indicators. The 2011 version of the EIS consists of 16 indicators from 8 different data sources in contrast to the 2010 scoreboard which incorporated 13 indicators from 6 different data sources. As far as possible the 2010 indicators were updated, two indicators were replaced by better-suited ones and three indicators were added (mainly in the area of eco-innovation outputs). As the data collection and compilation process is an ongoing effort in the Observatory, there is further scope to improve the quality of the underlying data in the future.

Country specific figures of the single indicators are weighted with the share of population in order to calculate an EU average which corrects for the bias of smaller Member States. Thus the EU average of a sub-indicator displays the 
weighted mean of all country specific data of the EU-27 Member States. The EU average of indicators that display absolute numbers (e.g. Domestic Material Consumption (DMC) and GDP to calculate the material productivity indicator) is built directly by summing up the underlying data. To compare countries within each indicator the EU average is equated with 100. Countries with higher figures than the EU average obtain a higher score than 100 and countries with lower figures achieve less, depending on the deviation from the EU average. Missing data are not replaced by estimations; countries for which data is not available do not get a result for the respective indicator. In order to exclude statistical outliers, the $5 \%$ and the $95 \%$ quintiles are introduced as thresholds. Values above/below the thresholds are replaced by the corresponding threshold value. The EU average is calculated with the data corrected by the thresholds. The score of the index in each of the five areas is calculated by the unweighted mean of the underlying indicators. Consequently each indicator has the same importance in the five areas. The overall scoreboard of an EU-27 Member State is calculated by the unweighted mean of the 16 subindicators in order to avoid bias by areas of the scoreboard which consist only of a few indicators.

\section{Environmental Audits (Eco-Audit) in Eco-industrial Projects}

The collection of data on which environmental performance indicators are based forms part of the eco-audit process. Eco-audits are implemented at the plant level and involve a trained auditor conducting a site-tour to collect data on plant performance. In practice it will involve the collection of statistical data on parameters such as emissions and resource use, the ranking of the plant according to various pre-set criteria, and professional judgements on qualitative indicators of performance. From this base set of raw data, the audit processing team can devise and disseminate - as appropriate - sets of indicators for specific target audiences. Two common forms of dissemination include the Annual Report (or corporate Environmental Report if separately available) as a communication tool with external stakeholders, and internal memos, containing information of a sufficiently sensitive nature to warrant it suitable only for internal consumption. The format and content of the format should be in line with GRI Guidelines, as these establish a common format that is both consistent between companies, and over time, allowing progress to be transparently assessed. Several reviews of current environmental reporting have pointed to the need for third-party verification of data in external environmental reports and the long-term interests of providing clear, consistent, and scientifically defensible data and once again GRI is a major proponent of this. 
The term environmental audit covers a wide range of activities based on formal evaluation of an organization's or a facility's performance in relation to environmental objectives. There are many different definitions reflecting different emphases and objectives, but the critical elements are that the audit should be objective, systematic and based on defined criteria. An environmental audit is a process for assessing the nature and extent of environmental concerns at an existing facility-an industrial plant, an abandoned site, a mine area, or any other site where industrial pollution problems are identified or anticipated. It is used to provide data on the extent of pollution in an industrial area, to quantify the scale of pollution at a particular site, or to examine the causes and potential remedies of problems at a facility (World Bank, 1995). In this context, several types of environmental audit can be distinguished, although with considerable overlap:

- Site audit: assesses onsite conditions and the extent of contamination problems - Liability audit: requested by potential purchasers or by financial institutions when considering investment or acquisition

- Compliance audit: addresses compliance with company policies and regulatory requirements

- Management system audit: reviews both technical and organizational aspects, usually within the context of corporate environmental strategy

- Waste minimization or pollution prevention audit: examines production and waste management systems to identify improvements

A site audit is often the first step in obtaining a quantitative understanding of pollution problems. In many cases, the audit allows an evaluation to be made of priorities and of the extent and cost of control and remediation measures. This information then shapes all remediation actions and investments. Some examples of the use of site audits in Bank-funded International projects are given in Box I.

\section{BOX- I}

Uses of Site Audits in Bank Projects

- In Bulgaria, an audit provided information on the extent and severity of contamination at a metal smelter.

- In Bolivia, audits were used to define environmental issues and provide a basis for discussions with potential investors in the mining and hydrocarbons sectors.

- In Algeria, audits were carried out on several major industries in the preparation of an industrial pollution management project.

- In Estonia, the IFC's preparation for investment in a cement plant included a detailed audit that provided the basis for an environmental management plan. 
The Eco-audit should provide a list of recommended actions, in terms of increasing cost-effectiveness in addressing the critical environmental issues. This list should include interim and long-term targets and a timetable for achieving them, together with an indication of the investments and other resources (human, information, and so on) that would be required. The following points relate to the procedures for the execution of an Eco-Audit (World Bank, 1995).

- Selection of auditors. Various forms of certification of environmental auditors are under discussion in different countries, but, in general, no formal qualifications or registration should be required for carrying out a site audit. Although many of the skills required for a site assessment are general environmental or engineering skills, it is important that the audit team contain personnel with detailed knowledge of the specific industry being addressed. Selection of auditors should follow the normal procedures for consultants. Arrangements should be made to allow bidders to become familiar with the site before the tender closure date.

- Briefing and terms of reference. It is essential that the consultants selected have a clear understanding of the objectives of the work, especially if it is to become part of the overall environmental assessment for the project. The Terms of Reference (TOR) of Environmental audit would therefore need to be as specific as possible.

- Preparation phase. An audit plan should be prepared describing the information required, the site visit schedule, and the site personnel to be involved or interviewed. A protocol may be prepared defining the specific information that will be sought during the site visit. The protocol should be provided to the enterprise well in advance of the visit. Available file information on the facility should be obtained and reviewed before the visit, and the audit plan should then be refined, if necessary.

- Execution of the audit. Active cooperation of the plant owners and managers is essential for a good result and should be secured in advance. Good coordination reduces delays and costs. Therefore site visits, interviews, and any sampling should be organized as early as possible. The site inspection should be carefully documented, to support the findings and recommendations and to provide a reference for future audits.

- Review of findings. It is important that the management in place be allowed to comment on the findings and recommendations of the audit.

\subsection{Multilateral Environmental Agreement and Environmental Audit}

Good governance, the process of making decisions and determining whether or not to implement them, is essential to ensuring that promises on environmental protection and sustainable development produce credible results. It is a key 
requirement for an effective institutional framework for sustainable development, one of the main themes at the United Nations Conference on Sustainable Development (or Rio+20) in Rio de Janeiro, Brazil to be held on 20-22 June 2012. National auditors and their audits play a critical role in supporting good governance by advancing accountability and transparency. They do so by providing practical, objective, and rigorous examinations of how environmental and sustainability programs, laws, regulations, and targets are managed, implemented, and monitored at the national and international levels. Some countries have regional auditors or evaluators who play a similar role. There are hundreds of Multilateral Environmental Agreements (MEAs) dealing with various environmental issues and they are the main method available under international law for countries to work together on global issues. The assessment of the implementation, compliance and effectiveness of multilateral environmental agreements is in many cases complicated and plagued with gaps in data, conceptual difficulties and methodological problems. Most Supreme Audit Institutions (SAIs) with their specific competencies are uniquely poised to assess these gaps and report to parliament and inform the national and international community on the basic question of availability and adequacy of data and information as well as about the compliance and effectiveness of government policy related to the international commitments made.

Generally, the role of the Supreme Audit Institutions (SAIs) is to audit government activities, compliance and spending. A Supreme Audit Institution (SAI) provides the highest level of external audit of government bodies in a country. Most SAIs reports their findings to a national legislative body that holds the government accountable. Being independent and presenting their reports also to the wider public, SAIs play a key role in building governance and accountability within their respective country. SAIs are the key to enabling and maintaining accountability as they supply the information needed by the legislature and the public to hold governments accountable. SAIs can undertake different kinds of audits aimed at ensuring better accountability. These include financial audits, assessing the accuracy and fairness of accounting procedures and financial statements; compliance audits, scrutinizing the use of funds for approved purposes through compliance with laws and regulations; and performance audits (also known as "value for money" audits), analyzing the operational efficiency and general effectiveness of government programmes. Environmental audits, like all other audits, essentially compare the current situation with what it should be. For public sector auditors of the environment, the audit criteria are derived from different sources like legislation and regulations, policies, programs, and enforcement requirements as well as multi-jurisdictional agreements (such as 
MEAs). Environmental audits also incorporate traditional audit criteria that are grounded in principles of good management and accountability.

\section{Policy Instruments to Support Eco-innovation}

Government policy initiatives and programmes that promote ecoinnovation are diverse and include both supply-side and demand-side measures. As most countries recognize the need for a more collaborative approach to innovation, many initiatives involve creating networks, platforms or partnerships that engage different industry and non-industry stakeholders. Demand-side measures are receiving increasing attention, as governments acknowledge that insufficiently developed markets are often the key constraint for eco-innovation. Eco- Indicators help businesses understand the environmental impacts of existing production systems, benchmark their performance, define specific objectives and monitor progress. No existing single set of indicators can cover all aspects that businesses need to address to improve environmental performance. Instead, a combination of existing indicator sets can help businesses gain a comprehensive picture of environmental impacts across the value chain. To improve understanding about eco-innovation for better policy making, the nature, drivers, barriers and impact of eco-innovation also needs to be captured at the macro (sectoral, local and national) level. Since no single method is again sufficient for the task, an "eco-innovation scoreboard" could be developed by combining different statistics and information.

Innovation policy needs to focus on system innovations to help in 'complying with the limits as it involves both the environmental and social dimension. Such an approach integrates the notion of limited resources and social sustainability, explicitly relating a set of social and environmental goals and the norms of economic (market) activity. As a complex policy challenge, support for ecoinnovation requires a coordinated approach - most notably between innovation, research and environmental policy. Implementation of eco-innovation measure has to be done in close collaboration and the levels of policy delivery following a common vision; a set of objectives and a strategy shared by all concerned stakeholders. Environmental policy agencies will have to cooperate more systematically with innovation policy-makers.

The main issue is to reduce risks for private investors investing in environmental $\mathrm{R} \& \mathrm{D}$ projects, while making sure that public money is used effectively and does not crowd out private initiatives. A variety of funds have been established to reduce risks to private investors (e.g. Sustainable Technology Development Canada-SDTC in Canada), or incubators (e.g. The Clean Energy Alliance in the US, Environmental Technology Business Incubator in Korea). Measures are taken 
to stimulate the venture capital industry and to provide incentives for environment-related projects; e.g. this is the role of the Environmental Venture Fund in Korea. Environment-related performance standards are being set with the aim of stimulating innovation in goods and services. Such standards are pursued in particular in the field of energy and resource efficiency. Schemes such as the Top Runner programme in Japan aim to address this challenge. Marketbased instruments are burgeoning in non-EU OECD Countries. A number of new projects and initiatives have been identified at national or local level. One interesting case is the all-encompassing Emission Trading Scheme envisioned in New Zealand, where equitable sharing of responsibility across sectors and stakeholders is based on the principle of equity across sectors. There is some evidence that, besides environmental policy instruments and regulation, soft instruments such as voluntary commitments, eco-audits and eco-labels play a role as determinants of innovative behaviour in firms. In line with the OECD Council Recommendation on Improving the Environmental Performance of Public Procurement, green procurement initiatives are burgeoning at local and national levels. Guidelines are supported by websites, green products databases, and pro forma requests for tenders. The Green Purchasing Network is an international network active in this area. Some initiatives set out to promote technologies and products developed by one country.

Eco-innovation is a new policy field, with few specific programmes developed in member States and scarce data on its importance and dynamics. While the 'eco innovation platform' and 'eco-innovation observatory' under Europe INNOVA will seek to better understand these dynamics and analyze data sources, the INNO-Net should develop expertise on the role to be played by public policies and actors in this field, in particular innovation agencies and programmes, most efficient approaches and results to be expected. The support provided to SMEs by eco-innovation policies should be analyzed in particular (INNO-Nets - Better policies and instruments in support of eco-innovation: http://www.proinnoeurope.eu/action/inno-nets-better-policies-and-instruments-support-eco-

innovation). Last, but not the least, efficient eco-innovation policies should be encouraged and promoted among eco-innovation actors, including eco-innovative businesses, in order to accelerate their development and optimize their impact on eco-innovation on the ground. By raising awareness on the issues at stake, on the role of public policies and best practices, the INNO-Net should contribute to the diffusion of information towards eco -innovation actors on the ground and to the reinforcement of the 'eco-innovation community'. Synergies with the Eco innovation Forum implemented under ETAP will be investigated for this purpose.

\section{Conclusions}


Eco-innovations are essentially the innovative ways to harness the clan/ green/eco- technologies to the potential advantage of setting up of chain of industries ( eco-clusters) that are eco-friendly and makes best uses of natural resources without detriment to the ecology. Eco-innovations also make best uses of wastes of all conceivable kinds generated from industries, conserve energy and help preserve biodiversity. Eco-innovations also encourages generation of ecofriendly products which are needed to be marketed with green branding and ecolabelling to create niche markets for eco-products. This will help create a new wave of eco-consciousness in one hand, open-up new business opportunities for eco-industrial enterprises with strong entrepreneurial quality on the other hand.

Findings of the paper suggest that there are various determinants of ecoinnovations that provide both potential and implicit limitations to green growth, which are attempted through continuous eco-innovations. Future promotion of eco-industries, established on the strength of sustainable eco-technology, will continue to depend, among other things, largely on providing funding support to $\mathrm{R} \& \mathrm{D}$ activities and planned priority to be given by eco-industries in future. Special efforts should be directed to replicate the successful sustainable models of eco-industrial parks under diverse ecological conditions to help reverse the ecological degradation caused by global climate change. Such efforts should go hand in hand with mitigation and adaptation programme initiatives with the active institutional support of green-funding mechanisms.

Performance measurement on eco-efficiency of both eco-industrial projects and eco-products will be the key drivers for ascertaining the success and failures of eco-industrial projects. Once the eco-projects establishes high performance and sustainability ratings based on measured performance indicators the scope of project expansion should be planned with economic analysis for ensuring longterm viability. Inter-organizational collaboration and sharing of $\mathrm{R} \& \mathrm{D}$ information will go a long way to add value to eco-industrial business initiatives in future.

\section{References}

Aggeri, F., (1999), Environmental policies and innovation: A knowledge-based perspective on cooperative approaches. Research Policy 28, 699-717.

Andersen, M. M. (2004), An Innovation System approaches to Eco-innovation - Aligning policy rationales. Paper presented at "The Greening of Policies - Inter-linkages and Policy Integration Conference", 3-4 December 2004, Berlin, Germany

Andersen, M. M. (2008), "Eco-innovation - theoretical and methodological considerations", DIME WP 2.5 Workshop on Empirical Analyses of 
Environmental Innovations, Fraunhofer Institute for Systems and Innovation Research ISI, 17-18th January, Karlsruhe, 2008.

Annice Laws (2010), Building a Green Brand Increased Market Share with Sustainability: http://greennurture.com/eco-article-dtl.aspx?id=48, Retrieved on March 17, 2010

Beaume R. and Midler C. (2009), From technology competition to reinventing individual eco-mobility: new design strategies for electric vehicles, International Journal of Automotive Technology and Management, 9 (2), 174-190

Brezet, H.; Van Hemel, C. Ecodesign (1997), A Promising Approach to Sustainable Production and Consumption; UNEP: Paris, France, 1997.

Carrillo-Hermosilla, J. P. Del Rio, and T. Könnölä (2010), "Diversity of eco-innovations: Reflections from selected case studies", Journal of Cleaner Production, vol. 18, 2010, pp. 1073-1083.

Chertow, M., W. Ashton and R. Kuppalli (2004), The Industrial Symbiosis Research Symposium at Yale - Advancing the Study of Industry and Environment, Yale Center for Industrial Ecology Report, No. 3, Yale Center for Industrial Ecology, Newhaven, CT.

Chesborough, H. W., Rosenbloom, R. S. (2002), The role of the business model in capturing value from innovation: Evidence from Xerox Corporation's technology spin-off companies. Industrial and Corporate Change, 11(3): 533-534.

Chesborough, H. W. (2003), Open Platform Innovation: Creating Value from Internal and External Innovation, Intel Technology Journal, 7(3), 5-9.

Chertow, M.(1999) "Industrial Symbiosis: A Multi-Firm Approach to Sustainability" The Eighth International Conference of the Greening of Industry Network: http://www.zeri.org/theory.htm

Christensen, Clayton M. (1997), The Innovator's Dilemma: When New Technologies Cause Great Firms to Fail. Boston, Mass.: Harvard Business School Press.

Cohen, D (2007), Earth's Natural Wealth: An Audit, New Scientist (2605).

Cortese, Amy (July 20, 2003),"They Care About the World (and They Shop, Too)". Business Section (New York Times), http://query.nytimes.com/gst/fullpage.html?res=9E01E3D8103CF933A15754C0A9659C8B63.

Co`te' RP, Hall J. (1995), Industrial parks as ecosystems, Journal of Cleaner Production 1995;3 (1,2):41-6.

Crul, M., J. C. Diehl, and C. Ryan (2009), Design for sustainability - A step-by-step approach. UNEP, Paris.

Das, T. K. and Teng, B.S. (2000), "A resource-based theory of strategic alliances", Journal of Management, 2000, 26 (1), 31-62

Das, T. K., Bing-Sheng Teng. (2002), The dynamics of alliance conditions in the alliance development process, Journal of Management Studies 39(5), p725 - 746.

Davis J.J. (1993), Strategies for environmental advertising, The Journal of Consumer Marketing 1993; 10(2):19-36.

Dess, G.G., Lumpkin, G.T., and Covin, J.G. (1997), Entrepreneurial Strategy Making and Firm Performance: Tests of Contingency and Configurational Models, Strategic Management Journal, 18 (9): 677-695. 
Easterling, D., Kenworthy, A. and Nemzoff, R. (1996), The greening of advertising: a twenty-five year look at environmental advertising, Journal of Marketing Theory and Practice, Vol. 4 No. 1, pp. 20-33.

ECOTEC (2002a), Analysis of the EU Eco industries, their employment and export potential, The Final Report for DG, Environment, ECOTEC Research \& Consulting Limited; Priestley House 28-34 Albert Street, Birmingham B4 7UD, United Kingdom.

ECOTEC (2002b), EU Eco-industries: Trade and international markets, ECOTEC Research \& Ed. Thousand edited by David Annandale, John Phillimore and Dora Marinova, Edward Elgar, Cheltenham, United Kingdom.

Environmentally-Friendly Promotional Products Can Aid Your Organization With "Green" Branding: http://www.igreen-home.com/environmentally-friendlypromotional-products-can-aid-your-organization-with-green-branding $/$; Retrieved on February 4, 2011 by The iGreen-Home Team

Esders, M (2008), Conceptualizing the Assessment of Eco-Innovation Performance: A Theory Based Framework for Deriving Eco-Innovation Key Performance Indicators and Drivers (EI-KPIs), Centre for Sustainability Management (CSM) e.V., Lueneburg, 2008.

European Commission (2002), RTD Evaluation Toolbox - Assessing the SocioEconomic Impact of RTD-Policies, IPTS Technical Report Series, EUR 20382 EN, published August 2002.

European Commission (2004), Stimulating Technologies for Sustainable Development: An Environmental Technologies Action Plan for the European Union, COM (2004) 38 final, Brussels.

Environmental Protection Agency (EPA), United States (2011), Green Servicizing: Building a More Sustainable Economy, internal working draft, EPA, Washington, D.C.

Eurostat/OECD (1999), The Environmental Goods \& Services Industry: manual for data collection and

Exploratory Study Using the Theory of Constraints in Nordic Organizations”, Business Strategy and the

Environment, Vol.18, pp. 277-290

EUROSTAT (2007), Measuring progress towards a more sustainable Europe, 2007 monitoring report of the EU sustainable development strategy, Luxembourg

EUROSTAT - Annual Activity Report (2010), Directorate A: Cooperation in the European Statistical System; Resources Unit A3: Strategic Planning; Learning and development, estat_aar_2010_final - 1 -

Everage, Laura (October 1, 2002). "Understanding the LOHAS Lifestyle", Gourmet Retailer Magazine (Nielsen Business Media).

http://www.gourmetretailer.com/gourmetretailer/magazine/article display.jsp? vnu_content id $=1738479$

Frondel, M; M. Horbach, J. \& Rennings, K. (2004a), What Triggers Environmental Management and Innovation? Empirical Evidence for Germany, RWI: Discussion Papers No. 15 
Frondel, M; M. Horbach, J. : Rennings, K \& Requate, T (2004b), Environmental Policy Tools and Firm-Level Management Practices: Empirical Evidence for Germany. RWI: Mitteilungen Quarterly, forthcoming.

Frondel, M., J. Horbach, K. Rennings (2007), End-of-Pipe or Cleaner Production? An Empirical Comparison of Environmental Innovation Decisions Across OECD Countries, Business Strategy and the Environment, Vol. 16 No. 8, 571-584.

Glaser, P. S. (2009, July 23), Green Power Marketing Claims: A Free Ride on Conventional Power? Electricity Journal, 12(6), Pages 32-40; Retrieved from Wiley InerScience Database. Malardalen University Library

Garvin, D. and Levesque, L. (2006) Meeting the challenge of corporate entrepreneurship. Harvard Business Review 84, 10, 102-112.

Hartmann P, Iba'ñez VA, Sainz JFF. (2005), Green branding effects on attitude: functional versus emotional positioning strategies, Marketing Intelligence and Planning, 23(1), 9-29.

ImagePower® Green Brands Survey, 2007

Johnson, M. and J. Suskewicz (2009), "How to Jump-Start the Clean- Tech Economy", Harvard Business Review, Reprint No. R0911D

Kaberger, T. (2003), Environmental labeling of electricity delivery contracts in Sweden, Energy Policy. 31(7), 633-640, Retrieved from Wiley InerScience Database, Malardalen University Library

Karna, J., Hansen. E., \& Juslin, H. (2003), Social responsibility in environmental marketing planning, European Journal of Marketing, 37 (5/6), 848-871.

Kemp, R and Arundel A. (1998), Survey Indicators for Environmental Innovation, IDEA Report, STEP

Leibenstein, H. (1968), 'Entrepreneurship and Development', American Economic Review, 58 (2): 72-83.

Lowe E, Moran S, Holmes D. (1995), A field-book for the development of eco-industrial parks. Report for the U.S. Environmental Protection Agency. Oakland (CA): Indigo Development International, 1995.

Luchsinger, V., and Bagby, D.R. (1987), Entrepreneurship and Intrapreneurship: Behaviors, Comparisons, and Contrasts, SAM Advanced Management Journal: 52 (3): 10-13.

Lumpkin, G., Dess, G.G. (1996), Clarifying the entrepreneurial orientation construct and linking it to

performance. Academy of Management Review 21 (1), 135-172

Lumpkin, G., Dess, G.G. (2001), Linking two dimensions of entrepreneurial orientation to firm performance: The moderating role of environment and industry life cycle. Journal of Business Venturing, 16, 429-451.

Lumpkin, G.T. \& Dess, G. G. (2004), Entrepreneurial Orientation, In Hitt, M.A.\& R. D. Ireland (Eds.) The Blackwell Encyclopedic Dictionary of Entrepreneurship (Blackwell Encyclopedia of Management). Oxford: Blackwell Publishing.

Lumpkin, G. T. and Lichtenstein, B. B. (2005), "The role of organizational learning in the opportunity recognition process", Entrepreneurship Theory and Practice, July, $451-472$ 
Machiba (2008), Sustainable Manufacturing and eco-innovation, First steps in building a common framework, OECD, DSTI/IND (2008)16/REV1.

Machiba, T. (2010), Eco-innovation for enabling resource efficiency and green growth: development of an analytical framework and preliminary analysis of industry and policy practices. International Economics \& Economic Policy, Vol. 7, Issue 2/3, p. 357-370.

Magretta, J. (2002), Why business models matter, Harvard Business Review, 80(5), 86-92.

Martin, M. (2009), "The Bio-gasification" of Linkoping: A Large Technical Systems Perspective", Environmental Technology and Management, Linköpings Universitet, Linköping.

Meenakshisundaram, R. and B. Shankar (2010), Business Model Innovation by Better Place: A Green Ecosystem for the Mass Adoption of Electric Cars, Oikos sustainability case collection, ICMR Center for Management Research, Hyderabad, www.oikos-international.org/projects/cwc.

Meffert, H. and Kirchgeorg, M. (1993), Marktorientiertes Umweltmanagement, SchaefferPoeschel, Stuttgart, Germany.

Menon A, Menon A. (1997), Enviropreneurial marketing strategy: the emergence of corporate environmentalism as market strategy. Journal of Marketing, 61: 51-67.

Mihashi, N. (1998) Zero Emissions and Japanese Economy, Iwanami-Shinsho, Tokyo, Japan

Miller, D. (1983), The correlates of entrepreneurship in three types of firms. Management Science, 29 (7), 770-791.

Nordic Council of Ministers (2010), Green Business Model of Nordic Region: A Key to promote Sustainable growth, A Green Paper, Nordic Council of Ministers, October, 2010

OECD and Eurostat (2005), Oslo Manual Guidelines for Collecting and Interpreting innovation data, third edition, Paris, Luxemburg Organizations", Business Strategy and the Environment, Vol.18, pp. 277-290

OECD (2008a), Environmental innovation and global markets, Working Party on Global and Structural Policies, ENV/EPOC/GSP (2007)2/FINAL, Paris

OECD (2008b), Sustainable manufacturing and eco-innovation: First steps in building a common analytical framework, DSTI/IND (2008)16/REV1, OECD, Paris

OECD (2009), Sustainable Manufacturing and Eco-Innovation: Framework, Practices and Measurement- Synthesis Report. OECD, Paris.

OECD (2010), 'Bologna +10' High-level Meeting on lessons from their Global crisis and the way forward to job creation and growth, OECD Working Party on SMES and Entrepreneurship (WPSMEE), 17-18 November, Paris

OECD (2010a), Eco-Innovation in Industry: Enabling Green Growth, OECD Publishing, Paris

OECD (2011), Oslo Manual: Guidelines for Collecting and Interpreting Innovation Data, 3rd Edition, http://www.oecd.org/document/23/0,3343,en_2649_34273_35595607_1 _1_1_37417, 00.html, 30.01.2011. 
OECD (2011a), Towards Green Growth, OECD Publishing, Paris

OECD (2011b), Fostering Innovation for Green Growth, OECD Publishing, Paris.

Osterwalder, A. (2004), The Business Model Ontology- A Position in a Design Science approach, Dissertation 173, University of Lausanne, Switzerland.

Osterwalder, A; Pigneur, Y., Tucchi, C.L. (2005), Clarifying business models: origins, present, and future of the concept. Communications of the AIS 15(May), 2-40.

Osterwalder, A and Pigneur, Y. (2010), Business Model Generation, New Jersey: John Wiley \& Sons, Inc., Hoboke

Ottman, J. 1993. Green Marketing: Challenges \& Opportunities for the New Marketing Age. NTC

Ottman, J. A., Stafford, E. R., \& Hartman, C. L. (2006), Avoiding Green Marketing Myopia: Ways to Improve Consumer Appeal for Environmentally Preferable Products, Environment, 48(5), 22-36

Pickett, G.M., Kangun, N. and Grove, S.J. (1995), "An examination of the conserving consumer: implications for public policy formation in promoting conservation behavior", in Polonsky, M.J. Mintu- Wimsett, A.T. (Eds) Environmental Marketing: Strategies, Practices, Theory and Research: The Howorth Press: New York, pp 77-99

Porter, M.E., van der Linde, C., (1995), Toward a new conception of the environment competitiveness relationship. Journal of Economic Perspectives 9(4), 97-118.

Rand Europe (2000a), "Stimulating industrial innovation for sustainability: An international Analysis”, Report for the Dutch Ministry of Housing, Spatial Planning and the Environment, Leiden.

Rand Europe (2000b), "Stimulating industrial innovation for sustainability: An international Analysis”, nine country reports, Leiden.

Reuer, Jeffrey and Olk Africa Arino (2011), Entrepreneurial Alliance, Prentice Hall, ISBN10: 0136156363 SBN-13: 9780136156369

Rivera-Camino, J. (2007), Re-evaluating green marketing strategy: a stakeholder perspective, European Journal of Marketing, 41(11-12), 1328-1358.

Schmidt-Bleek F. (1999), The Factor 10/MIPS-Concept: Bridging Ecological, Economic, and Social Dimensions with Sustainability Indicators, UNU/Zero Emissions Forum.

Schmidt-Bleek, F. (Ed.). (2004),Der ökologische Rucksack. Wirtschaft für eine Zukunft mit Zukunft. Hirzel, Stuttgart.

Schmidt-Bleek, F. (2009), The Earth: Natural Resources and Human Intervention. Haus Publishing Limited, London.

Schmidt-Bleek, F. (2010), Comments on the EIO methodological report, Factor 10 Institute Carnoules

Schumpeter, Joseph A. (1911), The Theory of Economic Development: An Inquiry into Profits, Capital, Credit, Interest and the Business Cycle. 1934 translation, Cambridge, MA: Harvard University Press 
Shane, S. and S. Venkataraman (2000), 'The Promise of Entrepreneurship as a Field of Research', Academy of Management Review, 25 (1): 217-26.

Tukker, A. (2004), "Eight types of Product-Service Systems: Eight Ways to Sustainability?" Business Strategy and the Environment, Vol. 13, pp. 246-260.

Tukker, A. and U. Tischner (2006), New Business for Old Europe: Product-service development, competitiveness and sustainability, Greenleaf Publishing, Sheffield.

Vaccaro, L., V. (2009), B-2-B Green Marketing and Innovation theory for competitive advantage, Journal of systems and Information Technology, 11(4), 315-330, Retrieved from Emerald Database. Malardalen University Library

Worcester, MA.Shultz, C.J. II and Holbrook, M.B. (1999), "Marketing and tragedy of the commons: a synthesis, commentary and analysis for action", Journal of Public Policy and Marketing, Vol. 18 No. 2, pp. 218-29.

World Bank (1995), “Environmental Auditing," Environmental Assessment Sourcebook Update 11, Environment Department, Washington, D.C.

Zott, C., Amit, R., Massa, L. (2011), The Business Model: Recent Developments and Future Research. Journal of Management, Volume: 37, Issue: 4 pp. 1019-1042 